(i)

EIJASR

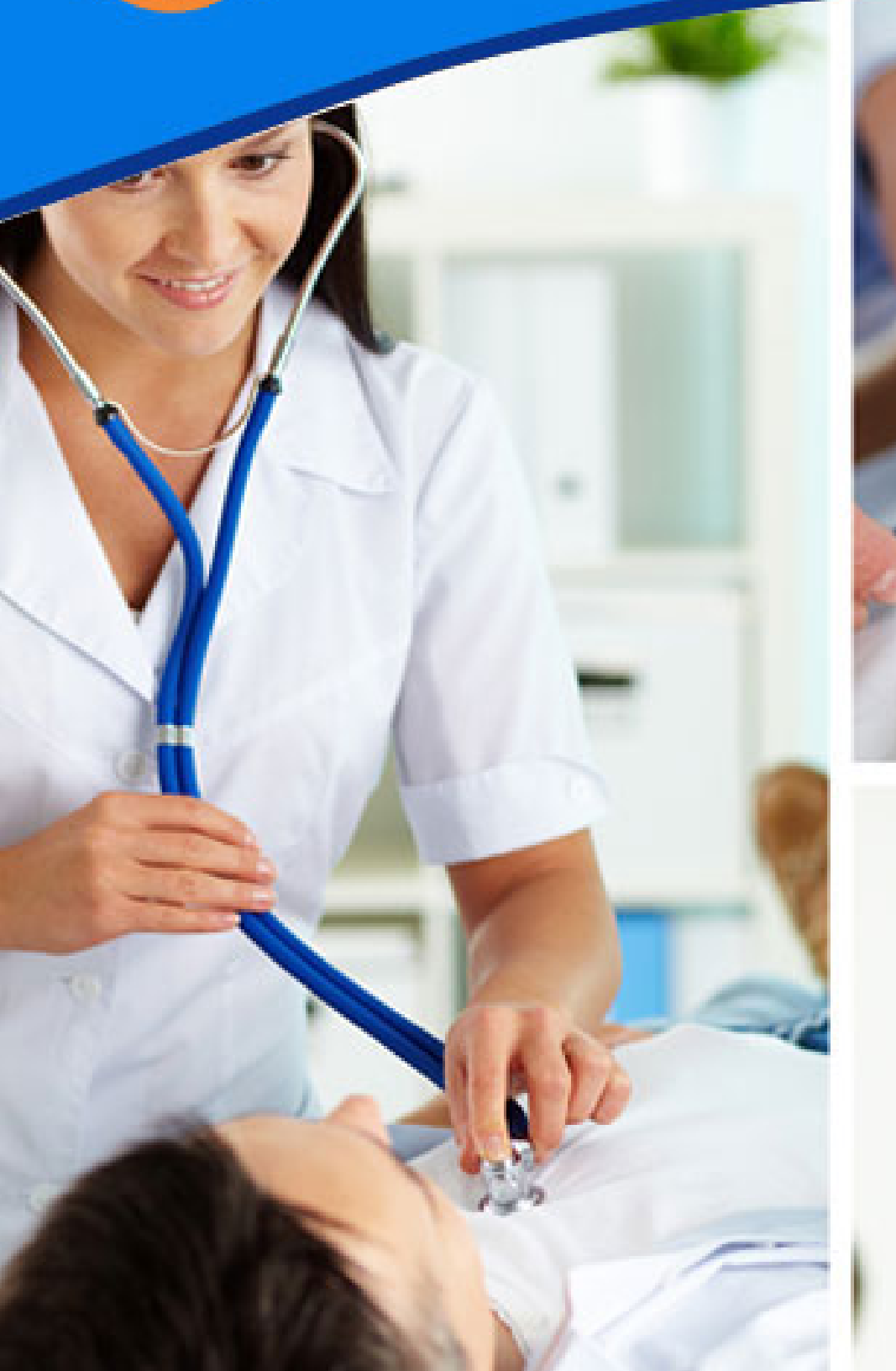




\title{
Relationship between students' performance in aptitude test at recruitment time and actual progressive performance during training at one of the Nursing Schools in Zambia
}

\author{
Article by Himoonga Mulenga \\ Universe, PhD student, $M S c N$, RTN, RN \\ Email: uniemulenga@yahoo.com
}

\begin{abstract}
General Nursing Council recruitment and selection guidelines requires passing of an aptitude test by candidates wishing to train as nurses, a prerequisite that has been received with mixed feelings due to the high failure rate inherent with the test. The investigator therefore undertook the study to determine if there was any relationship with passing of the aptitude test and the performance of students during training.

A purposive, retrospective review of records was done and IBM SPSS statistical package, version 20 was used to analyze data.

The findings revealed that passing the aptitude test, was not indicative of definite subsequent passing of the nursing courses by students. In conclusion passing aptitude test was not a determinant of ability of student to pass their nursing examinations.
\end{abstract}

Keywords: Aptitude, performance, nursing education, regulation.

\section{Introduction}

Nursing Regulation in Zambia started with the registration of nurses and midwives under the hospice of Northern Rhodesia Nurses Association in 1955 (M, C, Zyongwe and N, M Zyongwe 2010). At the time, the legal and constitutional stance was that the training of nurses in Northern Rhodesia (Zambia) could not be recognized by either General Nursing Council of England or Wales (the colonial masters) or the Medical Council of Southern Rhodesia (Zimbabwe) because the standards of training did not meet their requirements. Professional nurses then, were being trained in England and South Africa. Training of professional Nurses in Zambia started in 1964 after gaining independence at Kitwe (former Llewellyn) school of Nursing and this caused strong agitation for self regulation by the Nursing Association of Zambia, which led to the enactment of the Nurses and Midwives Act No 55 of 1970. This Act was repealed and replaced by the Nurses and Midwives Act No 31 of 1997, which extended the Scope of practice for nurses and midwives in Zambia. This Act outlined the functions of the Council to include, regulation of nursing and midwifery practice, as well as registration of nursing and midwifery colleges. On this bases, a number of standards have been set by the Council to provide guidance and standardization of activities in Nursing Colleges.

The recruitment and selection guidelines are one of the standards developed by General Nursing Council to guide Colleges when recruiting candidates to undertaking the nursing training. One of the requirements in these guidelines is that the candidates should pass an aptitude test which is administered by the Labour and Social Security government Department. This particular test has almost become the single determinant of who gets recruited into the system and because of the high failure rate inherent with the same test; it has been received with mixed feelings. Many educationists and stakeholders have condemned the test and there has been strong agitation to get rid of this particular requirement from the guidelines. The public whom the Council is mandated to protect by putting in place systems that ensures objectivity in the recruitment and selection process has condemned the particular criteria. The need for adopting the aptitude test was necessitated as a result of increasing number of individuals applying to undertake nursing courses but competing for very few places. This stimulated the need for an objective way of administering a competitive 
South American Journal of Nursing

Volume 2, Issue 1, 2016

recruitment assessment system. An independent administrator of this test was thought of to enhance transparency, standardization, and objectivity of the system. American Association of colleges of Nursing, (2011), experienced a surge of applicants into the Baccalaureate course, and 39.5\% raise in enrolment was reported. This report further pointed that more than 75,000 qualified applicants could not be given places to train. This simply highlights the need for putting in place convincing justifications why individuals have to be left out in such a competitive recruitment process.

However, it is worth noting that regulation of student entry into training colleges was not only peculiar to Zambia, Kevern J., et al (1999) reports high likelihood of completing training for those candidates that were well qualified. Kansas Medical University (2015), conducts Nurse Anaesthesia course and candidates recruited into this program are expected to posses over fifteen minimum entry requirements which the University has outlined.

Since there has been no study to establish the significance of the aptitude test to the nursing profession recruitment system, this investigation was instituted to find out if there is a relationship between student performance in aptitude test at recruitment time and actual progressive performance during training.

\section{Objectives of the study}

1. To establish if there is a relationship between the students' performance in aptitude at recruitment time and performance during training.

\section{Method}

This was a Retrospective study which was aimed at identifying if there was any relationship between passing of an aptitude test and progressive performance during training. A review of records of former students' performance in aptitude test at recruitment time and subsequent performance during training was undertaken. Purposive sampling method was utilized to select the study sample.

\section{Target population}

The target population included all records of students who were recruited into training in 2011, sat for an aptitude test at recruitment into nursing and completed their training in 2014.

\section{Accessible population}

The study population of interest that was reachable to the investigator and for this particular study, records of students recruited at Livingstone School of Nursing in Southern Province of Zambia was accessible to the investigator. The total number of files that were found at the School was fifty five (55). Out of these 55 records, only 21 had complete records and were purposively selected.

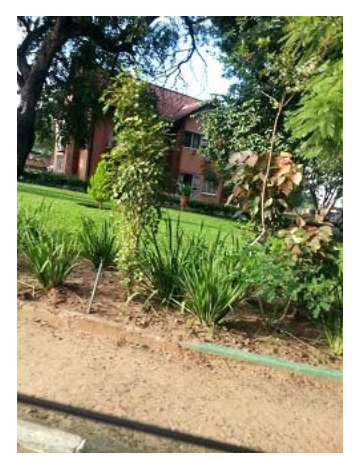

Administration block at block 


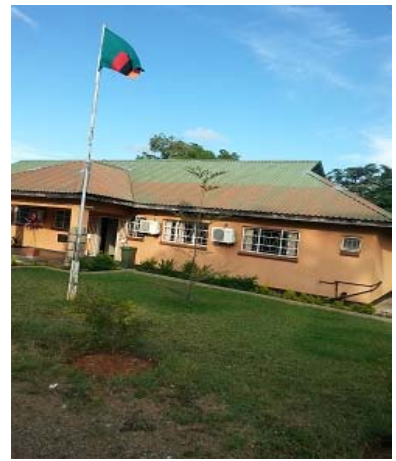

Livingstone school of nursing

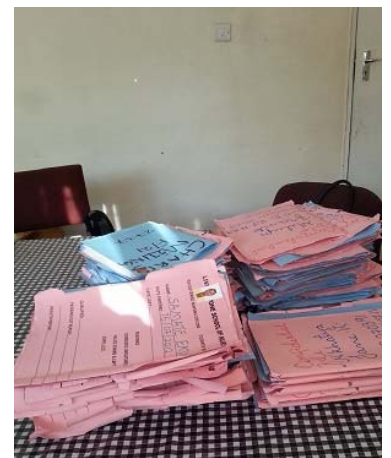

Picture of files for 2011

\section{Sampling method}

The target population comprised 55 files of former students and 21 were purposefully selected for review while 34 were left out since they contained incomplete data. Class result registers for the group was used to get the performance of each student and was compared with the performance during the aptitude test to determine if those that performed best at that time maintained the high performance. The records were sampled to determine the performance during aptitude test at recruitment time and a record of the subsequent performance during training was compared.

\section{Data collection method}

The category system was used, where all the characteristics of interest were identified, a checklist developed and used as a data collection tool. The check list included the performance of students in end of year qualifying examinations against the baseline aptitude score. The results of all the students during each year end was compiled and checked against the aptitude test score at recruitment time.

\section{Ethical consideration}

The study focused on the records of students who had since completed training and therefore written permission was sought from the medical superintendent to review the records at the School of Nursing. An informed consent was also signed by the principal tutor as the investigator sought access to the records. The accessed records were identified by numbers to enhance the anonymity of the students whose records were reviewed.

\section{Data analysis plan}

The data was analyzed using IBM SPSS statistics 20 license. The data was presented in frequency tables, histograms and cross tabulations. Descriptive statistics were utilized to explain the results of the study. 
South American Journal of Nursing

Volume 2, Issue 1, 2016

\section{Results}

Table 1. Showing student's Biographic data

\begin{tabular}{|l|l|l|l|l|}
\hline & Frequency & Percentage & $\begin{array}{l}\text { Valid } \\
\text { percentage }\end{array}$ & $\begin{array}{l}\text { Cumulative } \\
\text { percentage }\end{array}$ \\
\hline Age of Students & \multicolumn{2}{l|}{} \\
\hline Students less than 25 years & 9 & 47.4 & 47.4 & 47.4 \\
\hline $\begin{array}{l}\text { Equals or greater than } 25 \\
\text { years }\end{array}$ & 10 & 52.6 & 52.6 & 100.0 \\
\hline \multicolumn{7}{|l|}{} & $\mathbf{1 0 0}$ & 100 & \\
\hline Gender of the Students & $\mathbf{1 9}$ & 26.3 & 26.3 & 26.3 \\
\hline Male & 5 & 73.7 & 73.7 & 100.0 \\
\hline Female & 14 & 100.0 & 100.0 & \\
\hline Total & 19 & 89.5 & 89.5 & 89.5 \\
\hline Marital Status of students & 17 & 10.5 & 10.5 & 100.0 \\
\hline Single & 2 & 100.0 & 100.0 & \\
\hline Married & 19 &
\end{tabular}

Table 1 shows the biographic details of students and majority were above 25 years of age, 10 (52.6\%). Out of these 14 (73.7), were females and only 2 (10.5), were married.

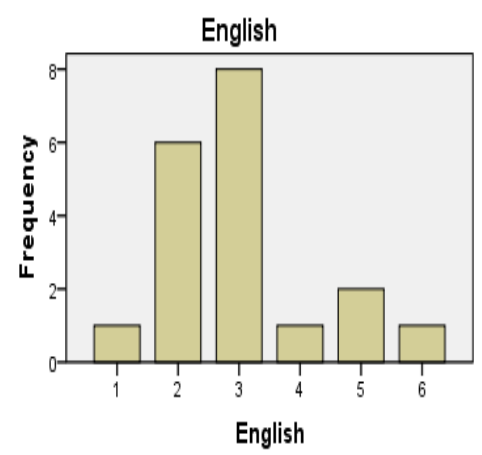

Figure 1

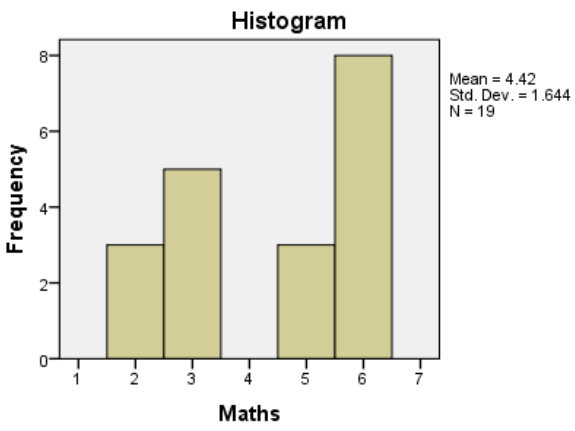

Figure 2 


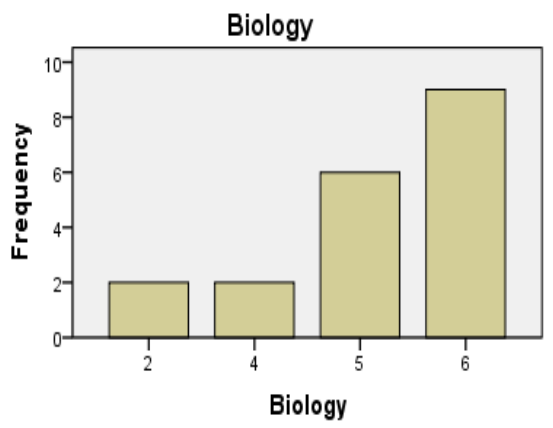

Figure 3

Figures 1, 2 and 3 shows the performance of all the students at high school in the three compulsory subjects. In figure 1 the majority scored a merit while in figure 2 and 3, the majority scored a credit.

Table 2. Year one Performance * Aptitude Score Cross tabulation

\begin{tabular}{|c|c|c|c|c|c|}
\hline & & & Aptitude Sco & & Total \\
\hline & & & $\begin{array}{l}\text { Pass (10 and } \\
\text { above } 10)\end{array}$ & $\begin{array}{l}\text { Fail (below } \\
10)\end{array}$ & \\
\hline & & Count & 1 & 0 & 1 \\
\hline & Passed & \% within Year one & | & (口) & l100 \\
\hline Year one & & Performance & $100.0 \%$ & U.0\% & $100.0 \%$ \\
\hline Performance & & Count & 4 & 14 & 18 \\
\hline & Fail & \% within Year one & $22.2 \%$ & $77.8 \%$ & $100.0 \%$ \\
\hline & & Count & 5 & 14 & 19 \\
\hline Total & & $\begin{array}{l}\text { \% within Year one } \\
\text { Performance }\end{array}$ & $26.3 \%$ & $73.7 \%$ & $100.0 \%$ \\
\hline
\end{tabular}

Table 2 indicates that only one student passed both aptitude and year 1examinations at first attempt. The rest of the students cleared their examinations after second attempt.

Table 3. Year two Performance * Aptitude Score Cross tabulation

\begin{tabular}{|c|c|c|c|c|c|}
\hline & & & Aptitude Sco & & Total \\
\hline & & & $\begin{array}{l}\text { Pass (10 and } \\
\text { above } 10)\end{array}$ & Fail (below 10) & \\
\hline & & Count & 2 & 10 & 12 \\
\hline & Passed & \% within Year two & $16.7 \%$ & 83.3\% & $100.0 \%$ \\
\hline Year two Performance & & Count & 3 & 4 & 7 \\
\hline & Failed & $\begin{array}{l}\text { \% within Year two } \\
\text { Performance }\end{array}$ & $42.9 \%$ & $57.1 \%$ & $100.0 \%$ \\
\hline & & Count & 5 & 14 & 19 \\
\hline Total & & $\begin{array}{l}\text { \% within Year two } \\
\text { Performance }\end{array}$ & $26.3 \%$ & $73.7 \%$ & $100.0 \%$ \\
\hline
\end{tabular}

During year two, table 3, most of the students who failed the aptitude test (83.3\%), past the end of year two examinations at first attempt. 
South American Journal of Nursing

Volume 2, Issue 1, 2016

Table 4. Year three Performance * Aptitude Score Cross tabulation

\begin{tabular}{|c|c|c|c|c|c|}
\hline & \multicolumn{2}{|c|}{ Aptitude score } & \multirow[t]{2}{*}{ Total } \\
\hline & & & $\begin{array}{l}\text { Pass }(10 \\
\text { and } \\
\text { above } \\
10)\end{array}$ & $\begin{array}{l}\text { Fail } \\
\text { (below } \\
10 \text { ) }\end{array}$ & \\
\hline \multirow{4}{*}{$\begin{array}{l}\text { Year three } \\
\text { Performance }\end{array}$} & \multirow[t]{2}{*}{ Passed } & Count & 4 & 13 & 17 \\
\hline & & $\begin{array}{l}\text { \% within Year } \\
\text { three } \\
\text { Performance }\end{array}$ & $23.5 \%$ & $76.5 \%$ & $100.0 \%$ \\
\hline & \multirow[t]{2}{*}{ Failed } & Count & 1 & 1 & 2 \\
\hline & & $\begin{array}{l}\text { \% within Year } \\
\text { three } \\
\text { Performance } \\
\end{array}$ & $50.0 \%$ & $50.0 \%$ & $100.0 \%$ \\
\hline \multirow[t]{2}{*}{ Total } & Count & 5 & 14 & 19 & Count \\
\hline & $\begin{array}{l}\% \text { within Year } \\
\text { three } \\
\text { Performance }\end{array}$ & $26.3 \%$ & $73.7 \%$ & $100.0 \%$ & $\begin{array}{l}\text { \% within Year } \\
\text { three } \\
\text { Performance }\end{array}$ \\
\hline
\end{tabular}

Table 4 shows that the majority of the students (76.5\%), who failed aptitude test past their year 2 end of year examinations on first attempt. Only one student failed end of year two examinations and apparently, this candidate had passed the aptitude test at entry into nursing school.

Table 5. Year 2 Practical * Aptitude Score Cross tabulation

\begin{tabular}{|c|c|c|c|c|c|}
\hline & \multicolumn{2}{|c|}{ Aptitude Score } & \multirow[t]{2}{*}{ Total } \\
\hline & & & $\begin{array}{l}\text { Pass (10 and } \\
\text { above } 10)\end{array}$ & Fail (below 10) & \\
\hline \multirow{4}{*}{$\begin{array}{l}\text { Year } 2 \\
\text { Practical }\end{array}$} & \multirow{2}{*}{ Passed } & Count & 3 & 12 & 15 \\
\hline & & \% within Year 2 Practical & $20.0 \%$ & $80.0 \%$ & $100.0 \%$ \\
\hline & \multirow{2}{*}{ Failed } & Count & 2 & 1 & 3 \\
\hline & & \% within Year 2 Practical & $66.7 \%$ & $33.3 \%$ & $100.0 \%$ \\
\hline \multirow{2}{*}{ Total } & & Count & & & \\
\hline & & \% within Year 2 Practical & $27.8 \%$ & $72.2 \%$ & $100.0 \%$ \\
\hline
\end{tabular}

Table 5 shows the performance of students in practical examinations at the end second year. Results indicated that 12 (80\%) of students who had initially failed the aptitude test past the practical examination at the end of first year.

Table 6. Year 3 Practical * Aptitude Score Cross tabulation

\begin{tabular}{|ll|l|l|l|}
\hline & & \multicolumn{2}{|l|}{ Aptitude Score } & Total \\
\cline { 3 - 4 } & & $\begin{array}{l}\text { Pass (10 and } \\
\text { above 10) }\end{array}$ & Fail (below 10) & \\
\hline $\begin{array}{l}\text { Year 3 } \\
\text { Practical }\end{array}$ & Passed & Count & 14 & 18 \\
Total & \% within Year 3 Practical & $22.2 \%$ & $77.8 \%$ & $100.0 \%$ \\
& Count & 14 & 18 \\
& \% within Year 3 Practical & $22.2 \%$ & $77.8 \%$ & $100.0 \%$ \\
\hline
\end{tabular}

Table 6, showed that all the students, (100\%) including those that had failed the aptitude test at enrolment, passed the practical examinations at the end of third year. 


\section{Discussion of findings}

General Nursing Council of Zambia has a mandate to regulate nursing education and one of the standards that guide training institutions is the recruitment and selection guidelines. These guidelines require that candidates applying to enter nurse training pass an aptitude test. The aptitude test consequently has eliminated a lot of candidates aspiring to train as nurses. Sometimes, when colleges fail to obtain the required number of applicants, they end up reducing the pass mark for the aptitude test leading to a situation where some of the recruited candidates may not have passed the aptitude test at recruitment but successfully completed their training. The aim of this study therefore was to identify if there was a relationship between passing aptitude test and subsequent performance during training. The results of the study revealed that majority of the respondents were aged 25 years $52.6 \%$ and above and mostly were females $73.7 \%$.

Table 2 indicated that only one student passed both aptitude and year 1 examinations at first attempt. The rest of the students cleared their examinations after second attempt. This picture did not clearly give guidance if there was a relationship between passing of the aptitude test and the subsequent performance in training. The results also may mean that there could have been a problem with the teaching system since the performance of all the students were very poor.

Tables 4, 5, and 6 revealed that most of the students who had failed aptitude test at the recruitment time, passed the end of second and third year examinations on first attempt, indicating that aptitude test was not the best determinant for selecting candidates that were educable. The aptitude test could have eliminated a lot of candidates who could have joined the profession but were not selected on the basis that they failed to pass the aptitude test. However, more research is required to evaluate the performance of the nurses that passed aptitude test at recruitment and those that did not pass at recruitment time.

Limitations of the study

The sample size was too small for the results to be generalized.

\section{Conclusion}

This study was set to investigate if there was any relationship between passing of an aptitude test and performance of students during nursing training. The performance of students was not consistent with the passing of the aptitude test. During year one, the poor performance in certain courses affected all the students despite passing the aptitude at recruitment time. In conclusion, this study has revealed that there was no correlation with passing of aptitude test and the progressive performance of the students during training. The investigator recommends that further research be undertaken to establish if there was a correlation between passing of aptitude and practical performance upon completion of training.

\section{Acknowledgements}

The author is indebted to Livingstone School of nursing and the management team for the permission granted to undertake the study and for their cooperation. The efforts and support by the course coordinator from Texila American University, Vanitha Prithiviraj cannot be overlooked. Thanks to TAU for according an opportunity to publish.

\section{References}

[1.] American Association of College of Nursing, (2011). New AACN Data Show an Enrollment Surge in Baccalaureate and Graduate Programs Amid Calls for More Highly Educated Nurses. http://www.aacn.nche.edu/news/articles/2012/enrollment-data

[2.] Burns N., and Grove S, K., (2003), Understanding Nursing Research. 3rd Edition. Sunders. Philadelphia. 
South American Journal of Nursing

Volume 2, Issue 1, 2016

[3.] Grimholt et al., (2014), Perceived competence and attitudes towards patients with suicidal behaviour: a survey of general practitioners, psychiatrists and internists http://www.biomedcentral.com/1472-6963/14/208

[4.] Hain, D., (2013), “Overview and Summary: Delivering Nursing Care: Current Factors to Consider". The Online Journal of Issues in Nursing Vol. 18, No. 2. http://nursingworld.org/MainMenuCategories/ANAMarketplace/ANAPeriodicals.OJIN/tableofcontents /vol18-2013/No2-May-2013/overviewandsummary-Delivering-Nursing-Care.html\#Hain

[5.] http://www.kumc.edu/school-of-health-professions/nurse-anesthesia-education/prospectivestudents/eligibility-and-requirements.html

[6.] Kervin J., et al (1999), Pre-registration diploma students: a quantitative study of entry characteristics and course outcomes. Journal of Advanced Nursing, volume 30, Issue No 4, pages 785 795.

[7.] Nieswiadom M, R., (2002), Foundations of nursing Research. 4th Edition. Upper Saddle River, New Jersey.

[8.] Polit F, D., and Hungler B, P., 1997, Essentials of Nursing research. Methods, Appraisal and utilization. 4th Edition, Lippincott. Philadephia.

[9.] Polit F, D., and Beck /c, T., (2004), Nursing Research. Principles and Methods. 7th Edition. Limppincott, Williams and principles. Wilkins, London.

[10.] Slaninka, S, C., (2011), Nursing Students Share Top Reasons for Being a Nurse. Copyright 2011 CMerion Matters • 2900 Horizon Drive, King of Prussia, PA 19406 • 800-355-5627, Publishers of Advance Newsmagazines • www.advanceweb.com

[11.] University of Kansas Medical center (2015), KU Nurse Anaesthesia Education.

[12.] Zyongwe M, C and., Zyongwe N, M, (2010), Development of Nursing in Zambia. 


\title{
Societal Contribution to Incidence of Puerperal Psychosis in Federal Psychiatric Hospital, Calabar, Cross River State, Nigeria
}

\author{
Article by Umoh, Edet Okon \\ Federal Psychiatric Hospital Calabar, Cross River State, Nigeria \\ Email: edetokonu@ymail.com
}

\begin{abstract}
The purpose of this study was to examine societal contribution in incidence of puerperal psychosis in Federal Psychiatric hospital, Calabar. In order to achieve this purpose, three research questions and three hypotheses were formulated to guide the study. The descriptive survey research design was used for the study. The population of study comprised all female psychiatric patients suffering from puerperal psychosis in Federal Psychiatric Hospital, Calabar. A convenience method of non-probability sampling was used to select sample for the study. This was made possible with in-patients' record from female wards in the hospital revealing a total of 50 patients. Instruments used for collection of data were questionnaires and face to face interview. The reliability of the instrument was established through internal consistency technique using Cronbach Alpha Analysis. A reliability estimate of 0.867 was obtained for the instrument. Chi-square statistical analysis was used for testing the hypotheses. All the hypotheses formulated were tested at. 05 level of significance. The result of the analysis revealed that acceptability of married women by family does significantly contribute to puerperal psychosis. Again, denial of pregnancy does significantly contribute to puerperal psychosis. Finally, the result revealed that continuous delivery of same sex children does significantly contribute to puerperal psychosis. Based on this findings, it was concluded that society do contribute to incidence of puerperal psychosis in Federal Psychiatric Hospital Calabar, Nigeria. It was therefore recommended that the media, traditional leader and religious organisations should educate the citizens on the importance of family members allowing married couples to live their life without undue intervention. Lastly, Government should enforce legislation to punish any man who for one reason or the other maltreats his wife.
\end{abstract}

Keywords: puerperium, psychosis, tranquilizer

\section{Introduction}

\section{Background of studies}

Puerperal psychosis also regarded as postpartum psychosis refers to sudden mental illness which manifests after child's birth. It is a serious form of mental illness in women during peuperium. It presents with sudden appearance of psychotic symptoms like irritability, mood swinging, hallucinations, restlessness, paranoid and suspicious ideas, homicide and sometimes suicide. In most cases the baby is at risk. It is always a surprised condition to the patient, family and health care provider- ${ }^{[15]}$ Twomey, T.(2009). The best approach is through psychiatry hospitalization- - ${ }^{[16]}$ Wikipedia, (Feb., 2016).

\section{Statement of problem}

It's common these days in third world countries like Africa to see most cultures maltreating married women who for one reason or the other experience delay in conception. Lots of disregard is observed on women who delivers same sex babies, especially female children. In some cases they are put on hard labour, made to feign for home keep, threatened to be divorced if they failed to be pregnant or deliver both sexes. Most families reject both baby and mother and pressurises the husband to bring in another woman who could deliver 
South American Journal of Nursing

Volume 2, Issue 1, 2016

them baby boys. These unfortunate happenings force most women to be under pressure, and for fear of being sacked; they live on extreme thoughts leading to puerperal psychosis.

This study is therefore poised against this background to examine how society contributes to puerperal psychosis in Calabar, Cross River State, Nigeria using Federal Psychiatric Hospital as a case study.

\section{Objectives of study}

Specifically, the objectives of the study include:

1. To examine the extent to which acceptability of a married woman by family members can contribute to puerperal psychosis

2. To determine the extent to which denial of pregnancy contributes to puerperal psychosis

3. To investigate the extent to which continuous delivery of same sex children contributes to puerperal psychosis.

\section{Research questions}

The following research questions were formulated to guide the study:

1. To what extent does acceptability of married women by family contributes to puerperal psychosis?

2. To what extent does denial of pregnancy contributes to puerperal psychosis?

3. To what extent does continuous delivery to same sex children contributes to puerperal psychosis?

\section{Hypothesis}

The following hypotheses were formulated to direct the study:

1. Acceptability of married women by family does not significantly contributes to puerperal psychosis

2. Denial of pregnancy does not significantly contributes to puerperal psychosis

3. Continuous delivery of same sex children does not significantly contribute to puerperal psychosis.

\section{Significant of study}

This study will be beneficial to nurses as they use knowledge to counsel married couples on proper relationship to prevent puerperal psychosis.

Knowledge acquired will be useful to health care providers in counselling society and extended family members to avoid stigmatizing the mentally ill women.

This material will serve as reference source to other researchers for further studies

It will assist government sensitize the public on maternal care in other to attain millennium development goal.

\section{Limitation of study}

Anticipated hindrance to this study is uncompromised attitude of the patients, staff, hospital management and patients' families towards providing necessary information for the study.

\section{Delimitation of study/scope}

This study covers all female patients with mental illness after child's birth in Federal Psychiatric hospital, Calabar.

\section{Literature review}

${ }^{[10]}$ Osianda, F. (1797) described puerperal psychosis as endogenous, acquired, occurring suddenly, not so harmful, and improves drastically with mood stabilizing agents. ${ }^{[2]}$ Doucet, S. et. al. (2011) said that symptom begins days or some weeks after delivery with incidence rate between $10-15$ of every 100 delivery. ${ }^{[3]}$ Gelder, 1996 said cause is unknown, but ${ }^{[8]}$ Marcé, 
L. V. (1862) and ${ }^{[4][5]}$ Jones, I. (2001) linked the cause to hormonal and chromosomal imbalance. ${ }^{[7]}$ Kaplain, (1994) and ${ }^{[14]}$ Stafford-Clark, D. (1978) emphatically said societal stress, frustration and increased workload has significant factor in causation. This was confirmed by William, V. (2016), as she enumerated her several pregnancies without an outstanding husband to shear the experience. Again, Igwe, C. (2004) revealed in secrecy that deliveries without a baby boy earn a woman no right and recognition in their tradition. ${ }^{[6]}$ Jones, I. and Smith, S. (2009) contributed that symptom ranges from mania to depression, hallucination, delusion and confusion, and is regarded as psychiatric emergencies. ${ }^{[13]}$ Robertson, E. (2005) suspected that it occurs after $20 \%$ subsequent child births. ${ }^{[12]}$ Reed, P. et. el. (1999) said it could be treated with Electro convulsive therapy. ${ }^{[9]}$ Oates, M (1988) found Lithium with other antipsychotic useful in its medication, and ${ }^{[1]}$ Almeida, Ana (2009) found hospital admission best for mother and child. This is followed up with home care after multidisciplinary review, counselling and nursing care.

\section{Theoretical framework}

${ }^{[11]}$ Peplau, E. (1999), theorized in her book 'Interpersonal Relationship in Nursing' that nurses should give wide information to the patient and the society about health matters. And she should make use of her learners' experience through their expression in further planning of healthcare.

\section{Relationship}

This refers to constant observation, documentation and reporting of findings to appropriate bodies especially the family. Through this, bizarre attitudes would be early detected, adequate measure and therapeutic action taken to prevent high risk, danger to child and others, even suicidal attempt.

\section{Methodology}

\section{Research design}

The research design of the study is descriptive survey.

\section{Population of study}

The population of study is all female psychiatric patients suffering from puerperal psychosis in Federal Psychiatric Hospital, Calabar.

\section{Sampling technique}

A convenience method of non-probability sampling is used. This is made possible with inpatients' record from female wards in the hospital revealing a total of 50 patients.

\section{Research instrument}

Instruments used for collection of data are questionnaires and face to face interview of participating patients.

\section{Validity}

The instrument was validated using face validation method where copies were given to experts to check if the items in the instrument measure the variable they are supposed to measure. Based on the useful suggestions and contributions of the experts, a valid instrument was developed by the researcher.

\section{Reliability}

In other to establish reliability co-efficient of the instrument, it was administered to 20 psychiatric patients who were drawn from the area of the study. The scores obtained from the respondents were subjected to internal consistency technique using Cronbach Alpha Analysis. 
South American Journal of Nursing

Volume 2, Issue 1, 2016

A reliability estimate of 0.867 was obtained for the instrument. The computation is presented in the appendix.

\section{Method of data analysis}

Chi-square statistical analysis was used for testing the hypotheses. All the hypotheses formulated were tested at. 05 level of significance.

\section{Data analysis and results}

The results obtained are analysed in the light of the research hypotheses formulated to guide the study.

\section{Hypothesis one}

Acceptability of married women by family does not significantly contribute to puerperal psychosis.

Chi-square $\left(\mathrm{X}^{2}\right)$ test was used for testing this hypothesis. The result of the analysis is presented in Table 1:

Table 1. Chi-square $\left(\mathrm{X}^{2}\right)$ test of the contribution of acceptability of married women by family to puerperal psychosis.

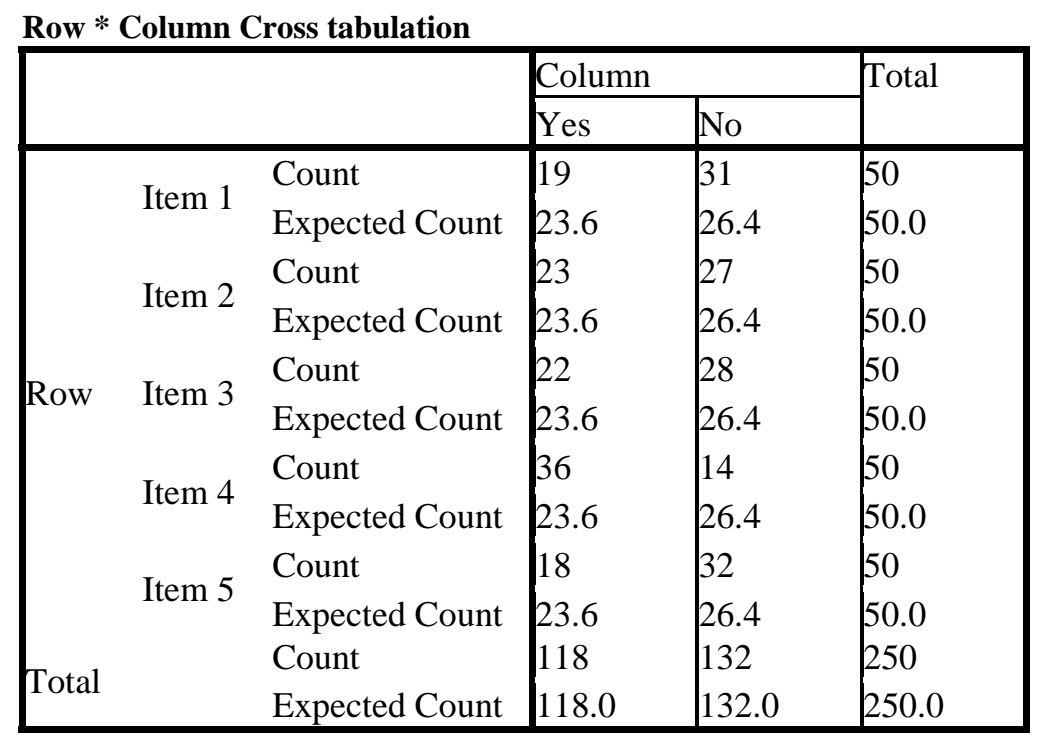

Chi-Square Tests

\begin{tabular}{|l|l|l|l|}
\hline & Value & Df & Asymp. Sig. (2-sided) \\
\hline Pearson Chi-Square & $16.789^{\mathrm{a}}$ & 4 & .002 \\
Likelihood Ratio & 17.158 & 4 & .002 \\
Linear-by-Linear Association & .967 & 1 & .325 \\
N of Valid Cases & 250 & & \\
\hline
\end{tabular}

The result in Table 1 shows that the calculated Chi-square $\left(\mathrm{X}^{2}\right)$ value of 16.789 is greater than the critical Chi-square $\left(\mathrm{X}^{2}\right)$ value of 9.49 at .05 alpha level with 4 degrees of freedom. With this result the null hypothesis that says acceptability of married women by family does not significantly contribute to puerperal psychosis was rejected. This implies that acceptability of married women by family significantly contribute to puerperal psychosis. 


\section{Hypothesis two}

Denial of pregnancy does not significantly contributes to puerperal psychosis

Chi-square $\left(\mathrm{X}^{2}\right)$ test was used for testing this hypothesis. The result of the analysis is presented in Table 2:

Table 2. Chi-square (X2) test of the contribution of denial of pregnancy to puerperal psychosis.

Row * Column Cross tabulation

\begin{tabular}{|lll|l|l|l|}
\hline & & & Column & Total \\
\cline { 3 - 4 } & & Yes & No & \\
\hline & \multirow{2}{*}{ Item 1 } & Count & 39 & 11 & 50 \\
& & Expected Count & 32.6 & 17.4 & 50.0 \\
& Item 2 & Count & 37 & 13 & 50 \\
& & Expected Count & 32.6 & 17.4 & 50.0 \\
Row & Item 3 & Count & 31 & 19 & 50 \\
& & Expected Count & 32.6 & 17.4 & 50.0 \\
& Item 4 & Count & 41 & 9 & 50 \\
& & Expected Count & 32.6 & 17.4 & 50.0 \\
& Item 5 & Count & 15 & 35 & 50 \\
& & Expected Count & 32.6 & 17.4 & 50.0 \\
Total & & Count & 163 & 87 & 250 \\
& & Expected Count & 163.0 & 87.0 & 250.0 \\
\hline
\end{tabular}

Chi-Square Tests

\begin{tabular}{|l|l|l|l|}
\hline & Value & Df & Asymp. Sig. (2-sided) \\
\hline Pearson Chi-Square & $39.066^{\mathrm{a}}$ & 4 & .000 \\
Likelihood Ratio & 38.471 & 4 & .000 \\
Linear-by-Linear Association & 16.997 & 1 & .000 \\
N of Valid Cases & 250 & & \\
\hline
\end{tabular}

The result in Table 2 shows that the calculated Chi-square $\left(\mathrm{X}^{2}\right)$ value of 39.066 is greater than the critical Chi-square $\left(\mathrm{X}^{2}\right)$ value of 9.49 at .05 alpha level with 4 degrees of freedom. With this result the null hypothesis that says denial of pregnancy does not significantly contribute to puerperal psychosis was rejected. This implies that denial of pregnancy significantly contribute to puerperal psychosis.

\section{Hypothesis three}

Continuous delivery of same sex children does not significantly contributes to puerperal psychosis

Chi-square $\left(\mathrm{X}^{2}\right)$ test was used for testing this hypothesis. The result of the analysis is presented in Table 3: 
South American Journal of Nursing

Volume 2, Issue 1, 2016

Table 3. Chi-square (X2) test of the contribution of continuous delivery of same sex children to puerperal psychosis.

\begin{tabular}{|c|c|c|c|c|c|}
\hline \multirow{2}{*}{\multicolumn{3}{|c|}{ Row * Column Cross tabulation }} & \multicolumn{2}{|c|}{ Column } & \multirow[t]{2}{*}{ Total } \\
\hline & & & Yes & No & \\
\hline \multirow{10}{*}{ Row } & \multirow{2}{*}{ Item 1} & Count & 43 & 7 & 50 \\
\hline & & Expected Count & 28.0 & 22.0 & 50.0 \\
\hline & \multirow{2}{*}{ Item 2} & Count & 22 & 28 & 50 \\
\hline & & Expected Count & 28.0 & 22.0 & 50.0 \\
\hline & \multirow{2}{*}{ Item 3} & Count & 24 & 26 & 50 \\
\hline & & Expected Count & 28.0 & 22.0 & 50.0 \\
\hline & \multirow{2}{*}{ Item 4} & Count & 33 & 17 & 50 \\
\hline & & Expected Count & 28.0 & 22.0 & 50.0 \\
\hline & \multirow{2}{*}{ Item 5} & Count & 18 & 32 & 50 \\
\hline & & Expected Count & 28.0 & 22.0 & 50.0 \\
\hline \multirow{2}{*}{ Total } & & Count & 140 & 110 & 250 \\
\hline & & Expected Count & 140.0 & 110.0 & 250.0 \\
\hline
\end{tabular}

Chi-Square Tests

\begin{tabular}{|l|l|l|l|}
\hline & Value & Df & Asymp. Sig. (2-sided) \\
\hline Pearson Chi-Square & $32.630^{\mathrm{a}}$ & 4 & .000 \\
Likelihood Ratio & 35.196 & 4 & .000 \\
Linear-by-Linear & 12.296 & 1 & .000 \\
Association & 250 & & \\
N of Valid Cases & & & \\
\hline
\end{tabular}

The result in table 3 shows that the calculated Chi-square $\left(\mathrm{X}^{2}\right)$ value of 32.630 is greater than the critical Chi-square $\left(\mathrm{X}^{2}\right)$ value of 9.49 at .05 alpha level with 4 degrees of freedom. With this result the null hypothesis that says continuous delivery of same sex children does not significantly contributes to puerperal psychosis was rejected. Hence continuous delivery of same sex children does significantly contribute to puerperal psychosis.

\section{Summary of the results}

The findings of the study are summarised below:

1. Acceptability of married women by family does significantly contribute to puerperal psychosis.

2. Denial of pregnancy does significantly contribute to puerperal psychosis.

3. Continuous delivery of same sex children does significantly contribute to puerperal psychosis.

\section{Discussion of findings}

The result of the first research hypothesis revealed that acceptability of married women by family significantly contributes to puerperal psychosis. This result is possible because in most third world countries, some cultures permits the family to choose a wife for the husband and in cases where the man disobeys and marry his choiced woman, the family members make the matrimonial home uncomfortable for them. This caused the wife's disregards which might result in depression and isolation, and in worst cases into puerperal psychosis. This confirms ${ }^{[6]}$ Jones, I. and Smith, S. (2009) view; that symptoms of puerperal psychosis ranges from mania to depression, hallucination, delusion and confusion, and is regarded as psychiatric 
emergencies. Meaning that depression, confusion and undue pressure from societal members could cause puerperal psychosis.

The result of the second research hypothesis revealed that denial of pregnancy does significantly contribute to puerperal psychosis. This finding is possible in that most families who do not undergo family planning end up having undesired number of children which in most cases are not always accepted by the men. Men reject both the wife and the baby if the pregnancy is not welcomed. This unfortunate development can subject the woman to thought and fear of being abandoned with baby, or sent packing.

The result of the third research hypothesis revealed that continuous delivery of same sex children does significantly contribute to puerperal psychosis. This is true due to the fact that most cultures especially in Africa attach importance to having male children. If a woman delivers female children severally; the husband and his kindred might threaten her replacement, ridicule and mockery. This finding supports ${ }^{[7]}$ Kaplain, (1994) and ${ }^{[14]}$ StaffordClark, D. (1978) who emphatically supports that societal stress, frustration and increased workload have significant factor in causation.

\section{Conclusion}

Based on the findings of the study, it was concluded that society do contributes to incidence of puerperal psychosis in Federal Psychiatric Hospital Calabar, Nigeria.

\section{Recommendation}

The following recommendations were made:

1. That the media, traditional leader and religious organisations should educate the citizens on the importance of family members allowing married couples to live their life.

2. Health caregivers should use their knowledge and experience to educate nursing mothers to dismiss pressures emanating from the society for whatever reason.

3. Government should enforce legislation to punish any man who maltreats his wife unnecessarily.

\section{Acknowledgement}

I acknowledge the Almighty God who strengthen and encourage me into this programme, without whom I would not have survived to foster.

I am grateful to my wife Nkoyo Edet Okon and children who assisted in domestic affairs, my Ward Charge and Head of Nursing Services Federal Psychiatric Hospital, Calabar for placing me on a favourable shift that permits me progress in these studies.

God bless them all.

\section{Reference}

[1.] Almeida, Ana; Merminod, Gaëlle; Schechter, Daniel S. (2009). "Mothers with severe psychiatric illness and their newborns: a hospital-based model of perinatal consultation". Zero to Three 29 (5): 406. ISSN 0736-8038.

[2.] Doucet S, Jones I, Letourneau N et al. (2011). Interventions for the prevention and treatment of postpartum psychosis: a systematic review. Archives of Women's Mental Health. 14(2): 89-98.

[3.] Gelder, M., Gath, D., Mayon, R., and Cowen, P. (1996) Oxford Textbook of Psychiatry, $3^{\text {rd }}$ Edition

[4.] https://en.wikipedia.org/wiki/Postpartum_psychosis

[5.] Jones, I.; Craddock, N (2001). "Familiality of the Puerperal Trigger in Bipolar Disorder: Results of a Family Study". American Journal of Psychiatry 158 (6): 913-7. doi:10.1176/appi.ajp.158.6.913. PMID 11384899.

[6.] Jones, Ian; Hamshere, M; Nangle, JM; Bennett, P; Green, E; Heron, J; Segurado, R; Lambert, D; Holmans, P; Corvin, A; Owen, M; Jones, L; Gill, M; Craddock, N (2007). "Bipolar Affective Puerperal 
South American Journal of Nursing

Volume 2, Issue 1, 2016

Psychosis: Genome-Wide Significant Evidence for Linkage to Chromosome 16". American Journal of Psychiatry 164 (7): 1099-104. doi:10.1176/appi.ajp.164.7.1099. PMID 17606662.

[7.] Jones I and Smith S (2009) Puerperal Psychosis: Identifying and caring for women at risk. Advances in Psychiatric Treatment. 15: 411-418.

[8.] Kaplan \& Sadock's (1994), Synopsis of Psychiatry: Behavioural Sciences/Psychiatry $10^{\text {th }}$ Edition

[9.] Marcé, L V (1862). Traité Pratique des Maladies Mentales [Practical Treatise on Mental Illness] (in French). Paris: Martinet. p. 146.

[10.] Oates, M (1988). "The development of an integrated community-orientated service for severe postnatal mental illness". In Kumar, R; Brockington, I F. Motherhood and Mental Illness: Causes and Consequences. London: Wright. pp. 133-58.

[11.] Osiander, Friedrich Benjamin (1797). "Glücklich gehobenes hitziges Fieber einer Wöchnerin mit Wahnsinn" [Happy young mother with a violent fever upscale madness]. Neue Denkwuerdigkeiten fuer Aerzte und Geburtshelfer [New memoirs for physicians and obstetricians] (in German) 1. Goettingen: Rosenbusch. pp. 52-128

[12.] Peplau, Hildegard E. (1998), Psychodynamic Nursing. In A. Tomey \& M. Alligood. Nursing Theorists and their Work (4th ed., pp. 337). St. Louis, Mosby.

[13.] Reed, P; Sermin, N; Appleby, L; Faragher, B (1999). "A comparison of clinical response to electroconvulsive therapy in puerperal and non-puerperal psychoses". Journal of Affective Disorders 54 (3): 255-60. doi:10.1016/s0165-0327(99)00012-9. PMID 10467968.

[14.] Robertson, E. (2005). "Risk of puerperal and non-puerperal recurrence of illness following bipolar affective puerperal (post-partum) psychosis". The British Journal of Psychiatry 186 (3): 258-9. doi:10.1192/bjp.186.3.258. PMID 15738508.

[15.] Stafford-Clark \& Smith, Andrew C. (1978), Psychiatry for Students $5^{\text {th }}$ Edition George Allen \& Unwin (Oublishers) Limited, Great Britain

[16.] Twomey, Teresa (2009). Understanding Postpartum Psychosis: A Temporary Madness. Westport, CT: Praeger. p. 12. ISBN 978-0-313-35346-8. 


\title{
Knowledge and Attitudes of Nurses towards Health Care Associated Infections in Lahore, Pakistan
}

\author{
Article by ${ }^{1}$ Muhammad Afzal ${ }^{*},{ }^{2}$ Ali Waqas, ${ }^{3}$ Muhammad Sabir, ${ }^{4}$ Shazma Ahmad \\ Khan, ${ }^{5}$ Aminullah \\ ${ }^{1}$ Assistant Professor, The University of Lahore, Pakistan \\ ${ }^{2}$ Visiting Lecturer, The University of Lahore, Pakistan \\ ${ }^{3}$ Lecturer, The University of Lahore, Pakistan \\ ${ }^{4}$ Visiting Lecturer, The University of Lahore, Pakistan \\ ${ }^{5}$ BSN student, The University of Lahore, Pakistan \\ Email: muhammad.afzal@lsn.uol.edu.pk
}

\begin{abstract}
This study assesses the knowledge \& attitudes of nurses regarding standard precautions about health care associated infections (HAIs) among the different hospitals of Lahore, Pakistan. Exposure to the body fluids and blood is the main sources for HAIs to the patients. Health care associated infection is a critical issue in the health care facilities because it causes mortality and infection among the hospitalized patients and health care workers. The World Health organization reported that ninety percent of infections among health care workers (HCWs) are associated with the occupational exposure to the body fluids and blood in the developing countries (Wilburn, et al., 2013). Standard precautions are used to provide the protection to health care providers from damages and to stop spread of nosocomial infection. Standard precautions recommend the proper hand hygiene before and after the procedure while contact with the patients (Boyce, et al., 2013).

The current study is of quantitative and cross-sectional design. Target population of the current study was 600 nursing staff of two hospitals of Lahore, Pakistan in which one is public hospital and other one is private hospital. The sample size of the current study was 172 which were calculated by using Slovin's formula. SPSS 20 was used for the data analysis.

The current study result shows that nurses have adequate knowledge regarding standard precautions of HAIs but lack the intention about precautions of HAIs. Thus, it is concluded that low level attitude of nursing staff regarding standards precautions about HAIs was assessed which cause infections to the health care providers and patients.
\end{abstract}

Keywords: Knowledge, Attitudes, Nurses, Standard precautions and Healthcare associated infections (HAIs).

\section{Introduction}

Healthy lifestyle is the life long effort to balance the activities of our life at every movement. Therefore, many situations may affect this balance and deprive our life from happiness. Among these situations, exposure to the body fluids and blood are the main sources for healthcare associated infections (HAIs). HAIs is a critical issue in the health care facilities because of its common cause of mortality and infection among the hospitalized patients and health care providers. Healthcare facilities are classified into biological, chemical, ergonomic, mechanical, physical and psychosocial.

The World Health Organization reported that ninety percent of infections among health care workers (HCWs) are attributed to the occupational exposure to the body fluids and blood in the developing countries (Wilburn, et al., 2013).

Healthcare associated infections (HAIs) can be defined as a systemic or localized condition that happens from an adverse exposure or reaction of the presence of an infectious agent that happens during hospital admission and there is no evidence that the infection was incubating 
South American Journal of Nursing

Volume 2, Issue 1, 2016

or present at the time of admission. Eriksen (2012) stated that incidence of health care associated infections are increased in Europe and United States within last 5 years.

Mbaisi (2013) investigated the health care sector of Kenya and emphasizes that the accidental occupational contact of healthcare workers to blood and body fluids subsequent to skin injury or mucous membrane contact comprises a risk for transmission of blood-borne pathogens. Moreover, the study describes that $25 \%$ of health care workers reported that they have been exposed to the blood and body fluids, overall 55.5\% nurses were commonly injured during injection procedure to the patients, $78.9 \%$ during stitching, $25 \%$ laboratory personnel during blood specimen collection while $57.1 \%$ supportive staff during cleaning.

Afridi (2013) reported the reasons for needle stick injuries (NSIs) in Pakistan that $42 \%$ of nurses exposed to the needle stick injury during injecting medicine and drawing blood and $37 \%$ of nurses exposed to needle stick injury during two-handed recapping of needle. Furthermore, 34\% of the nurses were vaccinated against hepatitis B infection. However, nurses had inadequate facilities at workplace concerning standard precautions such as $40 \%$ of nurses have accessibility of gloves / protective cloths and $10 \%$ of nurses fulfil protocols / infection control guidelines.

Serrano (2016) noted that overall prevalence rate of healthcare associated infections (HAIs) was $10.2 \%$. Palliative care units and subacute care units have highest rate of HAIs that is $22.3 \%$ and $18.7 \%$ respectively. However, common infections were respiratory tract infection and urinary tract infection in long term care facilities.

Siegel (2012) emphasizes that proper implementation of standard precaution decreases the rate of healthcare associated infections (HAIs) from both unknown sources and expected sources in the healthcare setting. Moreover, implementation of standard precautions decreases the transmission of respiratory infections, human Immunodeficiency virus (HIV), hepatitis B (HBV) and other pathogens which grow in the blood and body fluids and minimize the risk of HAIs among nurses and other health care providers.

Magill (2014) highlighted that health care associated infections (HAIs) are increasing in U.S as $4.0 \%$ of the patients keep at least 1 health care-associated infection. Pneumonia and surgical-site infection were most common, subsequently gastrointestinal infection, primary bloodstream infection and urinary tract infection.

\section{Study purpose}

The purpose of this study is to assess the knowledge \& attitude of nurse regarding standard precautions of Healthcare Associated Infections (HAIs) in different health care facilities of Lahore, Pakistan.

\section{Significance of the study}

This study provides awareness among the health care providers in different hospitals \& explores the knowledge and attitudes of nurses' related standard precautions towards healthcare associated infections and its implementations. The study results will be helpful to the policy makers of different hospitals to develop the strategies for enhancement of knowledge and attitude of nurses. Similarly, the study will contribute to reduce the HAIs.

\section{Objectives of the study}

1) To determine the level of knowledge of nurses regarding standards precautions about healthcare associated infections (HAIs) in hospitals of Lahore, Pakistan.

2) To determine the level of attitude of nurses regarding standards precautions about healthcare associated infections (HAIs) in hospitals of Lahore, Pakistan.

\section{Literature review}

Hand hygiene is acknowledged as one of the most important strategies for preventing healthcare associated infections (HAIs). During observations, it has been noticed that $40 \%$ of health care workers (HCW) adhere with contact precautions or use of gloves, masks and 
gowns while patients care (Septimus, et al., 2014). Furthermore, implementation of universal precautions has decreased the HAIs such as $44 \%$ reduction in all-cause bloodstream infection and 37\% of MRSA clinical culture rates (Septimus, et al., 2014).

In addition, environmental contamination is the major determinant of transmission of HAIs to healthcare workers and patients. Morgan (2012) found that during routine clinical care of patients, $62 \%$ of HCWs who entered the patients' room wearing the contaminated gloves, mask, and gown. In developing countries, environmental contamination, malnutrition and frequently usage of invasive devices are major cause of HAIs. It has observed that invasive procedure or devices cause 73\% HAIs in the hospitalized patients (Polin, et al., 2012). Moreover, proper utilization of universal precautions in ICUs decreases $40 \%$ to $50 \%$ of HAIs (Polin, et al., 2012).

The prevalence rate for HAIs has increased globally over the past 2 decades due to invasive procedures or devices such as mechanical ventilator, central venous catheter (CVC), arterial catheter, indwelling urinary catheter and wound drainage tube. Invasive procedure causing overall $55 \%$ of HAIs in which urinary tract infection is $54.8 \%$, blood stream infection is $30.6 \%$, surgical site infection is $6.6 \%$, pneumonia is $4.5 \%$ and other site infection is $3.5 \%$ (Yang, et al., 2013).

Improvement in the hand hygiene of HCWs decreases the transmission of pathogens, therefore, hand hygiene is widely accepted as a foundation to avoid the infections. Ellingson (2014) mentioned that adherence with 5 practices of hand hygiene reduces more than $50 \%$ of transmission of pathogens to the ICU patients. These practices are: wash hands before (1) touching a patient, (2) clean / aseptic procedure, and after (3) body fluid exposure, (4) touching a patient and (5) touching patient surrounding.

A number of strategies have been investigated for the prevention of HAIs spread among nurses and hospitalized patients in which hand washing has been proven to be a significant component of interventions for the reduction of HAIs. Angelis (2014) analyzed that proper utilization of hand hygiene measures significantly (47\%) decreases the rate of HAIs among nurses and patients.

Riven (2015) assessed the range of microorganisms found on noninvasive portable clinical items potentially shared among patients (NPIs) and evaluate the evidence regarding the potential for cross-transmission of microorganisms between NPIs and hospitalized patients in non-outbreak conditions. Subsequently, the study result shows that those rates of NPI contamination ranged from $23 \%$ to $90 \%$. Normal skin or environmental floras were found on almost all positive cultures.

Kirk (2016) emphasizes that $25 \%$ of health care providers follow the standard precautions during patient care. However, as compared to knowledge the attitude of nurses was disappointingly less regarding the precautions about the HAIs.

\section{Research methodology}

Cross sectional descriptive study design was used to assess the knowledge and attitude of nurses regarding standards precaution of healthcare associated infection in the hospitals of Lahore. The data were obtained through the adapted questionnaire of Knowledge and attitude regarding HAIs of Parmeggiani (2010) which is based on 5 point Likert scale. Target population of the study was 600 registered nurses of the hospitals of Lahore, Pakistan. The data was collected from two hospitals (Nawaz Sharif Social Security Hospital \& Doctors Hospital) of Lahore, Pakistan. Sample size of the current study was calculated by using Slovin's formula ( $\mathrm{n}=172)$, so, self-administered questionnaire was distributed to 172 nurses by simple random sampling technique. The inclusion criteria for this study were registered nurses while the student nurses and head nurses excluded. Period of the study was February 2016 to May 2016. 
South American Journal of Nursing

Volume 2, Issue 1, 2016

\section{Data analysis \& results}

Reliability of the tool checked through Cronbach's alpha. Data was collected from both male and female nurses in which $83.7 \%(\mathrm{n}=144)$ were females and $16.3 \%(\mathrm{n}=28)$ were males. Majority of nurses that is $79.6 \%(\mathrm{n}=132)$ of participants belong to age group $20-35$ years in which $59.3 \%$ were single and only $40.7 \%$ were married. Data shows that $89.5 \%(n=154)$ nurses have General Nursing Diploma and 10.5\% ( $n=18)$ has BS Nursing degree.

Table 1. Wearing gloves, mask, and protective eyewear are a HAIs control measures

\begin{tabular}{|ll|l|l|l|l|}
\hline & Frequency & Percent & $\begin{array}{l}\text { Valid } \\
\text { Percent }\end{array}$ & $\begin{array}{l}\text { Cumulative } \\
\text { Percent }\end{array}$ \\
\hline \multirow{6}{*}{ Valid } & Strongly Disagree & 5 & 2.9 & 2.9 & 2.9 \\
& Disagree & 15 & 8.7 & 8.7 & 11.6 \\
Neutral & 44 & 25.6 & 25.6 & 37.2 \\
& Agree & 51 & 29.7 & 29.7 & 66.9 \\
Strongly Agree & 57 & 33.1 & 33.1 & 100.0 \\
Total & 172 & 100.0 & 100.0 & \\
\hline
\end{tabular}

Responses regarding knowledge of Health Care Workers (HCWs) or nurses are reported in Table1. Majority 62.8\% $(\mathrm{n}=108)$ of nurses were aware that wearing of gloves, mask, and protective eyewear reduce the risk of HAIs although $11.6 \%(n=20)$ did not know that wearing of gloves, mask, and protective eyewear control the HAIs.

Table 2. Invasive procedures are a risk factor for HAIs

\begin{tabular}{|ll|l|l|l|l|}
\hline & Frequency & Percent & Valid Percent & $\begin{array}{l}\text { Cumulative } \\
\text { Percent }\end{array}$ \\
\hline \multirow{4}{*}{ Valid } & Strongly Disagree & 8 & 4.7 & 4.7 & 4.7 \\
& Disagree & 11 & 6.4 & 6.4 & 11.1 \\
Neutral & 47 & 27.3 & 27.3 & 38.4 \\
& Agree & 46 & 26.7 & 26.7 & 65.1 \\
& Strongly Agree & 60 & 34.9 & 34.9 & 100.0 \\
& Total & 172 & 100.0 & 100.0 & \\
\hline
\end{tabular}

In Table 2, 61.6\% $(\mathrm{n}=106)$ of the respondents knew that invasive procedures are a risk factor for HAIs while $11.1 \%(\mathrm{n}=19)$ disagree that invasive procedures are risk factors for HAIs.

Table 3. HCWs' hands are a vehicle for transmission of nosocomial pathogens

\begin{tabular}{|l|l|l|l|l|}
\hline & Frequency & Percent & Valid Percent & $\begin{array}{l}\text { Cumulative } \\
\text { Percent }\end{array}$ \\
\hline \multirow{2}{*}{ Valid } & 7 & 4.1 & 4.1 & 4.1 \\
Disagree & 17 & 9.9 & 9.9 & 14.0 \\
Neutral & 45 & 26.2 & 26.2 & 40.1 \\
Agree & 54 & 31.4 & 31.4 & 71.5 \\
Strongly Agree & 49 & 28.5 & 28.5 & 100.0 \\
Total & 172 & 100.0 & 100.0 & \\
\hline
\end{tabular}

Table 3 depicts that preponderance 59.9\% $(n=103)$ believed that HCWs' hands are a vehicle for transmission of nosocomial pathogens although $14 \%(n=24)$ respondents believed that HCWs are not accountable in transmission of nosocomial infection to the patients. 
Table 4. Hands hygiene measures reduce the risk of HAIs among patients

\begin{tabular}{|cl|l|l|l|l|}
\hline & Frequency & Percent & Valid Percent & $\begin{array}{l}\text { Cumulative } \\
\text { Percent }\end{array}$ \\
\hline \multirow{2}{*}{ Valid } & Strongly Disagree & 10 & 5.8 & 5.8 & 5.8 \\
Disagree & 20 & 11.6 & 11.6 & 17.4 \\
Neutral & 41 & 23.8 & 23.8 & 41.3 \\
Agree & 52 & 30.2 & 30.2 & 71.5 \\
Strongly Agree & 49 & 28.5 & 28.5 & 100.0 \\
Total & 172 & 100.0 & 100.0 & \\
\hline
\end{tabular}

Concerning the perceived risk of acquiring healthcare associated infections (HAIs), health care workers (HCWs) and nurses are at high risk for transfer of infections to the patients and among other health care workers. Table 4 shows that $57.8 \%(n=101)$ of nurses believes that good hand hygiene of health care workers (HCWs) reduce the risk of HAIs among patients while $17.4 \%(n=30)$ did not know that hand hygiene of health care workers (HCWs) reduce the risk of HAIs.

Table 5. Hands hygiene measures reduce the risk of HAIs among HCWs

\begin{tabular}{|ll|l|l|l|l|}
\hline & Frequency & Percent & Valid Percent & $\begin{array}{l}\text { Cumulative } \\
\text { Percent }\end{array}$ \\
\hline \multirow{6}{*}{ Valid } & Strongly Disagree & 11 & 6.4 & 6.4 & 6.4 \\
& Disagree & 17 & 9.9 & 9.9 & 16.3 \\
Neutral & 41 & 23.8 & 23.8 & 40.1 \\
& Agree & 56 & 32.6 & 32.6 & 72.7 \\
Strongly Agree & 47 & 27.3 & 27.3 & 100.0 \\
Total & 172 & 100.0 & 100.0 & \\
\hline
\end{tabular}

Table 5 shows that nurses had an extremely positive attitude, so, 59.9\% $(n=103)$ of total emphasize that guideline of HAIs should be followed because hands hygiene measures reduce the risk of HAIs among HCWs, however 16.3\% (n=28) nurses did not believe it.

Table 6. Aprons and face masks should be worn in procedures where splash/spill of blood is likely

\begin{tabular}{|ll|l|l|l|l|}
\hline & Frequency & Percent & Valid Percent & $\begin{array}{l}\text { Cumulative } \\
\text { Percent }\end{array}$ \\
\hline \multirow{4}{*}{ Valid } & Strongly Disagree & 9 & 5.2 & 5.2 & 5.2 \\
& Disagree & 13 & 7.6 & 7.6 & 12.8 \\
Neutral & 41 & 23.8 & 23.8 & 36.6 \\
& Agree & 67 & 39.0 & 39.0 & 75.6 \\
& Strongly Agree & 42 & 24.4 & 24.4 & 100.0 \\
& Total & 172 & 100.0 & 100.0 & \\
\hline
\end{tabular}

Table 6 shows that $63.4 \%(n=109)$ of nurses perceived that wearing of aprons and face masks decrease the HAIs during procedures where splash/spill of blood is likely, though $12.8 \%(n=22)$ of nurses do not distinguish that proper wearing of aprons and face masks decrease the HAIs during procedures where splash/spill of blood is likely.

\section{Discussion}

The current study examines the level of knowledge \& attitudes of nurses of Lahore, Pakistan about healthcare associated infections (HAIs). The result proves that nurses and HCWs have enough knowledge regarding hand hygiene and wearing of gloves, masks, and 
South American Journal of Nursing

Volume 2, Issue 1, 2016

protective eyewear during patient care as tools to control the HAIs. Similarly, the study results of Asadollahi (2015) and Hosseinialhashemi (2015) that nurses have sufficient knowledge about hand hygiene and wearing of protective measures but they need to more emphasize on the training of hand hygiene for the improvement in the attitudes and practice. Similarly, Kirk (2016) emphasizes that nurses and doctors have more knowledge as compare to the attitude regarding prevention of HAIs.

Numerous studies support that the effect of knowledge and attitude of nurses and health care workers to reduce HAIs transmitted by hand. HAIs is critical to the healthcare facilities and increases the risks, prevalence of diseases and hospital costs. HAIs results in 4 to 5 hospitalization days and adds significant cost to the hospitals. However, hand hygiene is the most valuable means of prevention of HAIs. The current study results proved that nurses and HCWs have knowledge regarding importance of hand hygiene in HAIs but only $60 \%$ health care workers focusing on hand hygiene practices, therefore, HAIs are high in developing countries. Similarly, Jain (2015) analyzed the knowledge and attitude of doctors and nurses towards HAIs and found that only $57 \%$ of the respondents fulfil hand hygiene measures during patient care and invasive procedures, therefore, HAIs also high in such hospitals. The results of this study show that $57.6 \%$ of nurses agree that healthcare associated infections are control by proper measure, $6 \%$ participants were disagreeing and rest of the participants have given neutral response.

The healthcare providers in any healthcare systems should be well aware of effectiveness of HAIs control measures. The poor attitude of HCWs and nurses indicates a strong need of on job healthcare providers (nurses) trainings in the developing countries to control HAIs (Kanwar, et al., 2015).

\section{Conclusion}

Standard precautions are the repetitive action that may lead to the foundation of a habit and it may influence behavior which depends on the knowledge. Nurses and health care workers (HCWs) show high level of knowledge regarding prevention of healthcare associated infections (HAIs), but low attitude regarding standard precautions about HAIs. It is urgency to start on job training programs for HCWs for bringing change in their attitude. Furthermore, to motivate HCWs through different incentives for implementation of standard precautions because this practice ultimately decreases the rate of HAIs and patient stay in the hospital.

\section{Limitations}

There are some limitations of the current study. First, it offers as a cross-sectional study, only depends upon specific questions. Target population was nurses and low health care workers; therefore it ignores the participation of doctors and pharmacist due to shortage of time. Second limitation is the potential recording bias associated with the self-administered questionnaire. Third, the current study only investigates two hospitals of Lahore due to the time constraints which may not be generalizable to the other parts of the country.

\section{Recommendation}

The findings of the current study provide the valuable baseline data for further investigation and intervention. Future researchers may conduct interventional and qualitative study on large scale and also include the physicians, surgeons, pharmacist and other health care workers. Authorities should enhance the knowledge and attitude of health care team for the attainment of better result. The future research may do the comparison of level of knowledge and attitude among the nurses of public and private universities. 


\section{References}

[1.] Asadollahi, M., Bostanabad, M. A., Jebraili, M., Mahallei, M., Rasooli, A. S., \& Abdolalipour, M. (2015). Nurses' knowledge regarding hand hygiene and its individual and organizational predictors. Journal of caring sciences, 4(1), 45.

[2.] Boyce, J. M., \& Pittet, D. (2002). Guideline for hand hygiene in health-care settings: recommendations of the Healthcare Infection Control Practices Advisory Committee and the HICPAC/SHEA/APIC/IDSA Hand Hygiene Task Force. American journal of infection control, 30(8), S1-S46.

[3.] De Angelis, G., Cataldo, M. A., De Waure, C., Venturiello, S., La Torre, G., Cauda, R., \& Tacconelli, E. (2014). Infection control and prevention measures to reduce the spread of vancomycinresistant enterococci in hospitalized patients: a systematic review and meta-analysis. Journal of Antimicrobial Chemotherapy, dkt525.

[4.] Ellingson, K., Haas, J. P., Aiello, A. E., Kusek, L., Maragakis, L. L., Olmsted, R. N., \& VanAmringe, M. (2014). Strategies to prevent healthcare-associated infections through hand hygiene. Infection Control \& Hospital Epidemiology, 35(08), 937-960.

[5.] Eriksen, H. M., Iversen, B. G., \& Aavitsland, P. (2005). Prevalence of nosocomial infections in hospitals in Norway, 2002 and 2003. Journal of Hospital Infection, 60(1), 40-45.

[6.] Europe, W. (2012). Management of Hepatitis C and HIV co-infection-Clinical protocol for the WHO European Region. Last accessed September, 12.

[7.] Hosseinialhashemi, M., Kermani, F. S., Palenik, C. J., Pourasghari, H., \& Askarian, M. (2015). Knowledge, attitudes, and practices of health care personnel concerning hand hygiene in Shiraz University of Medical Sciences hospitals, 2013-2014. American journal of infection control, 43(9), 1009-1011.

[8.] Jain, M., Dogra, V., Mishra, B., Thakur, A., \& Loomba, P. S. (2015). Knowledge and attitude of doctors and nurses regarding indication for catheterization and prevention of catheter-associated urinary tract infection in a tertiary care hospital. Indian journal of critical care medicine: peer-reviewed, official publication of Indian Society of Critical Care Medicine, 19(2), 76.

[9.] Kanwar, V., Sood, A., Gupta, P. K., \& Salaria, N. (2015). Knowledge regarding infection control practices among nurses in rural public health settings: an emerging public health concern in India. Int $\mathrm{J}$ Health Sci Res, 5(2), 282-287.

[10.] Kirk, J., Kendall, A., Marx, J. F., Pincock, T., Young, E., Hughes, J. M., \& Landers, T. (2016). Point of care hand hygiene-where's the rub? A survey of US and Canadian health care workers' knowledge, attitudes, and practices. American journal of infection control.

[11.] Magill, S. S., Edwards, J. R., Bamberg, W., Beldavs, Z. G., Dumyati, G., Kainer, M. A., \& Ray, S. M. (2014). Multistate point-prevalence survey of health care-associated infections. New England Journal of Medicine, 370(13), 1198-1208.

[12.] Mbaisi, E. M., Wanzala, P., \& Omolo, J. (2013). Prevalence and factors associated with percutaneous injuries and splash exposures among health-care workers in a provincial hospital, Kenya, 2010. Pan African Medical Journal, 14(1).

[13.] Mody, L., Meddings, J., Edson, B. S., McNamara, S. E., Trautner, B. W., Stone, N. D., \& Saint, S. (2015). Enhancing resident safety by preventing healthcare-associated infection: a national initiative to reduce catheter-associated urinary tract infections in nursing homes. Clinical Infectious Diseases, 61(1), 86-94.

[14.] Morgan, D. J., Rogawski, E., Thom, K. A., Johnson, J. K., Perencevich, E. N., Shardell, M., \& Harris, A. D. (2012). Transfer of multidrug-resistant bacteria to healthcare workers' gloves and gowns after patient contact increases with environmental contamination. Critical care medicine, 40(4), 1045.

[15.] Parmeggiani, C., Abbate, R., Marinelli, P., \& Angelillo, I. F. (2010). Healthcare workers and health care-associated infections: knowledge, attitudes, and behavior in emergency departments in Italy. BMC infectious diseases, 10(1), 1.

[16.] Polin, R. A., Denson, S., Brady, M. T., Papile, L. A., Baley, J. E., Carlo, W. A., \& Byington, C. L. (2012). Strategies for prevention of health care-associated infections in the NICU. Pediatrics, 129(4), e1085-e1093. 
South American Journal of Nursing

Volume 2, Issue 1, 2016

[17.] Septimus, E., Weinstein, R. A., Perl, T. M., Goldmann, D. A., \& Yokoe, D. S. (2014). Approaches for preventing healthcare-associated infections: go long or go wide?. Infection Control \& Hospital Epidemiology, 35(07), 797-801.

[18.] Serrano, M., Barcenilla, F., Limón, E., Pujol, M., \& Gudiol, F. (2016). [Prevalence of healthcareassociated infections in long-term care facilities in Catalonia. VINCat Program]. Enfermedades infecciosas y microbiologia clinica.

[19.] Siegel, J., et al. (2012). Guideline for isolation precautions: preventing transmission of infectious agents in health care settings: American journal of infectio control.

[20.] Wilburn SQ, Eijkemans G. (2013). Preventing needlestick injuries among healthcare workers: a WHO-ICN collaboration.

[21.] Yang, S. P., Chen, Y. Y., Hsu, H. S., Wang, F. D., Chen, L. Y., \& Fung, C. P. (2013). A risk factor analysis of healthcare-associated fungal infections in an intensive care unit: a retrospective cohort study. BMC infectious diseases, 13(1), 1. 


\title{
Sources of Stress among the Nursing Students of Private Universities of Pakistan
}

\author{
${ }^{1}$ Muhammad Afzal ${ }^{*},{ }^{2}$ Ali Waqas, ${ }^{3}$ Muhammad Hussain, ${ }^{4}$ Naveed Sehar \\ ${ }^{1}$ Assistant Professor, The University of Lahore, Pakistan \\ ${ }^{2}$ Visiting Lecturer, The University of Lahore, Pakistan \\ ${ }^{3}$ Lecturer, The University of Lahore, Pakistan \\ ${ }^{4}$ BSN student, The University of Lahore, Pakistan \\ Email: muhammad.afzal@lsn.uol.edu.pk
}

\begin{abstract}
The emotional situation or demand of the work from the student may create stress among the nursing students. Stress for the students at class room is very common and altered their mental and physical health. Similarly, the tiring nature of clinical practice also reduce the performance and ability to gain the knowledge of the nursing students. Thus, aim of the current study is to investigate the sources of stress among the nursing students. The study consists of a sample of122 nursing students of the private universities of Lahore. The study results reveals that students of nursing experiences stress through the following four sources i.e. academics, clinical rotation, personal problems and environment. Furthermore, nursing students of private universities experiences more stress from the academic sources of stress than the other three categories. The study provides the recommendations and implications in the future findings.
\end{abstract}

Keywords: Stress, academic sources, clinical sources, personal sources, environmental sources, nursing students.

\section{Introduction}

Stress refers to a dynamic interaction between the individual and the environment where demands, limitations and opportunities related to work may be perceived as threat to surpass the person's capacity and skills (Edward, et al., 2015). Stressors can be defined as the conditions or events that have the potential to affect health (Pulido, 2012). Stress is the person's reaction to any exceeding demand at workplace. In addition, stress also provides the means to show creativity, abilities and energies; though it can also cause fatigue and sickness, either physical or psychological (Edward, et al., 2015). However, nursing students also face stress due to the different sources and clinical rotation during studies. Thus, stress being the psychological factor also influences the student's academic performance (Findik, et al., 2015).

During university life where the passionate relationship between the student and environment is unpredictable, thus, stress observation and reaction has key importance. Although, every profession is effected by stress but the health professionals are more susceptible to stress especially the nursing professionals (Edwards, et al., 2010). Stress among students may arise from the stressors like academic sources, environmental sources and may be due to emotions or personal issues. These stressors might disturb the student's learning capability and academic performance (Hayes, et al.,2015). Thus, it enhances the need to focus on the factors which causes student's stress. Furthermore, the study describes stress as a link among person and their atmosphere that is considered as hazardous (Hayes, et al., 2015).

Nursing students are more prone to stress as they have pressure of clinical placements along with study, workload of assignments, fear of failure, inability to balance study and leisure time (Findik, et al., 2015). Likewise, nursing students face pressures during the clinical rotation like handling of advanced technology, variation between the standard operating procedures and real situations in the healthcare environment, on-cooperative 
South American Journal of Nursing

Volume 2, Issue 1, 2016

behavior of clinical staff, fear of making mistakes during patient care and humiliating behavior of physicians. Beside these stressors, there are various other sources of stress among nursing students like personal and environmental issues i.e. congested class room environment contributes a lot to create stress (Edward, et al., 2015). However, personal issues such as decline in personal health, financial problems, lack of sleep, high parental expectations, lack of confidence and decision making ability are major sources of stress among nursing students (Edward, et al., 2015).

The identification of sources of stress among nursing students will bring a positive change in student's performance as well as teacher's attitude towards students which is somehow hostile and ignoring (Shaban, et al., 2012). Thus, current study investigates the sources of stress among nursing students to avoid the damages and further development in the nursing profession.

\section{Research problem}

It is observed that students of private universities face stress. Moreover, nursing students face many issues that hinder the student's capabilities. It is need of the time that researchers should investigate the sources of stress among nursing students so that those factors which create negative influence on the student's academic performance can be avoided.

\section{Significance of study}

The current study investigates the sources of stress among nursing students of private universities of Lahore, Pakistan. The current study will be beneficial for the institutions and hospitals to identify the sources of stress at class room lectures and clinical practices. In addition, the findings of the current study will be helpful for the government and planning authorities to develop the strategy to diminish the sources of stress for the nursing students of private and public universities. Moreover, the results of this study will be useful to the nursing and medical institutes to decrease the key stress elements for the students.

\section{Research objectives}

The objectives of the current study are given in the following:

1) To identify the academic sources of stress among nursing students

2) To identify the clinical sources of stress among the nursing students.

3) To identify the personal sources of stress among the nursing students

4) To identify the environmental sources of stress among the nursing students.

\section{Literature review}

Common stressors for nursing students were identified in the previous studies academic courses, clinical placements, personal and environmental issues. Academic stressors like over burden of work, exam, the fear of failure and concerns associated with academic staff have been recognized (Pulido, et al., 2012). Negative perception towards nursing profession, disrespectful attitude of physicians towards nurses and humiliating behavior of staff are collective sources of stress among the nursing students (Cohen, 1981). Likewise, work load of assignments and clinical rotation become the reason of nursing student's low academic performance (Zhao, et al., 2015).

Nursing student's clinical placement also produces stress where students experience destruction from the standardized practices, indifference from more experienced nurses, hostile environment in hospital wards and criticism from staff and patients (Pulido, et al., 2012).

Additionally, students also face stress due to some personal sources or characteristics like low confidence and it has significant relationship with student's academic performance (Kim, et al., 2010).“The study emphasizes that academic factors contribute the highest level of stress among the Saudi nursing students, followed by environmental factors while interpersonal factors has the lowest influence (Abeer Saad Eswi, 2013). Likewise, the study reveals that 
most significant stressor among African nursing students in USA is academics sources, financial sources and interpersonal sources (Pryjmachuk, et al., 2007). The financial status of the students was one of the most associated factors related to stress among university students (Redhwan, et al., 2009). Lim, (2008) emphasizes that student's health is also important to be considered as the personal source of stress.

In view of the potential long term benefits of managing stress in a more effective way, it is important for students to develop such skills early in their medical career (Lim et al., 2008). Therefore, the current study aimed to explore the sources of stress among nursing students of University level, so that they can identify the stressors and may develop the strategy to cope them.

\section{Methodology}

The cross sectional study design is selected because the study is conducted on the limited scale and in limited time duration. The target population of the current study was the nursing students of private institutes. The convenient sampling technique was used and the nursing students of The University of Lahore were selected for data collection. Participant's confidentiality and privacy was assured and the letter of permission was obtained from the head of department of Lahore school of Nursing, to proceed the research. Time line for this study was from January,2016 to May, 2016. Total population of the nursing students at Lahore school of Nursing department was175 and Slovin's formula applied to calculate the sample size on the basis of available population. Thus, the sample size of the current study was 122 nursing students. The study includes the students who were enrolled for Post RN BS Nursing, 2 years and BSNursing4-year degree program in nursing department of The University of Lahore, Pakistan.

Self-administered questionnaire technique was used to distribute the questionnaire to the nursing students. The questionnaire of stressors among nursing students (Academic sources, clinical sources, personal and environmental sources) of Zhao (2015) which was based on 5point Liker scale was used to collect the data. The questionnaire was distributed to the participants through the faculty in the class room and 15 minutes were given to fill the questionnaire. SPSS 21 version was used to analyze the data and descriptive analysis test was performed to test the frequencies, percentages and graphical representation. Cronbach alpha has described to test the reliability of the instrument. Similarly, KMO and Bartlett's test was applied to test the validity of the instrument

\section{Results and analysis}

Descriptive analysis of the current study is given in the following

\section{Demographics}

\section{Gender}

Nursing students of the University of Lahore participated in the current study. Total 122 nursing students participated in this study. The distribution of demographics is given in the table 1. It shows the respondent's gender distribution. The results show that females were in majority in the respondents as $60.7 \%$ whereas, $39.3 \%$ males participated in current study.

Table 1. Gender

\begin{tabular}{|ll|l|l|l|l|}
\hline & Frequency & Percent & Valid Percent & $\begin{array}{l}\text { Cumulative } \\
\text { Percent }\end{array}$ \\
\hline \multirow{4}{*}{ Valid } & Male & 48 & 39.3 & 39.3 & 39.3 \\
& Female & 74 & 60.7 & 60.7 & 100.0 \\
& Total & 122 & 100.0 & 100.0 & \\
\hline
\end{tabular}


Table 2. Age

\begin{tabular}{|l|l|l|l|l|}
\hline & Frequency & Percent & $\begin{array}{l}\text { Valid } \\
\text { Percent }\end{array}$ & $\begin{array}{l}\text { Cumulative } \\
\text { Percent }\end{array}$ \\
\hline Below 20years & 6 & 4.9 & 4.9 & 4.9 \\
20 - 25years & 60 & 49.2 & 49.2 & 54.1 \\
Valid $26-$ 30years & 48 & 39.3 & 39.3 & 93.4 \\
Above30years & 8 & 6.6 & 6.6 & 100.0 \\
Total & 122 & 100.0 & 100.0 & \\
\hline
\end{tabular}

The distribution of nursing student's age is between 18 to 50 years is given in table 2. The results show the distribution of the age of respondents as $49.2 \%$ from age group of $20-25$, $39.3 \%$ were from age group of $26-30,4.9 \%$ were from below 20 years and $6.6 \%$ belongs to the age of above 30 years.

Table 3. Professional Qualification

\begin{tabular}{|ll|l|l|l|l|}
\hline & Frequency & Percent & $\begin{array}{l}\text { Valid } \\
\text { Percent }\end{array}$ & $\begin{array}{l}\text { Cumulative } \\
\text { Percent }\end{array}$ \\
\hline \multirow{5}{*}{ Valid } & Diploma in General Nursing & 9 & 7.4 & 7.4 & 7.4 \\
& Diploma in Midwifery & 1 & .8 & .8 & 8.2 \\
Both General Nursing and & 72 & 59.0 & 59.0 & 67.2 \\
& Midwifery & 40 & 32.8 & 32.8 & 100.0 \\
No Professional Education & 122 & 100.0 & 100.0 & \\
Total & &
\end{tabular}

The distribution of nursing student's qualification is given in table 3. The results show that the $59 \%$ of the students have qualified both Diploma in General Nursing \& Midwifery. However, $32.8 \%$ of the respondents had no professional qualification.

Table 4. Professional experience

\begin{tabular}{|ll|l|l|l|l|}
\hline & Frequency & Percent & Valid Percent & $\begin{array}{l}\text { Cumulative } \\
\text { Percent }\end{array}$ \\
\hline \multirow{4}{*}{ Valid } & No Experience & 40 & 32.8 & 32.8 & 32.8 \\
& $2-8$ Years & 76 & 62.3 & 62.3 & 95.0 \\
& $9-14$ Years & 3 & 2.5 & 2.5 & 97.5 \\
& 15 - 20 Years & 3 & 2.5 & 2.5 & 100.0 \\
& Total & 122 & 100.0 & 100.0 & \\
\hline
\end{tabular}

The distribution of nursing student's experience is given in table 4 . The results show that $63.2 \%$ of the respondents have experience of $2-8$ years whereas $32.8 \%$ of the respondents have no experience

\section{Reliability and validity}

To observe the reliability of the instrument of the current study, Cronbach Aplha test is used and the Cronbach Alpha value of the current study instrument is 0.877 that shows the reliability of the instrument. Moreover, the validity of the instrument is also tested through $\mathrm{KMO}$ and Bartlett's test as the results show that KMO value is $0.747(>0.50)$ and Bartlett's test is significant $(\mathrm{P}<0.05)$, which show that instrument is valid. 
Table 5. Validity of Instrument

\begin{tabular}{|c|c|c|}
\hline \multicolumn{2}{|l|}{ KMO and Bartlett's Test } & \\
\hline $\begin{array}{l}\text { Kaiser-Meyer-Olkin Measure of Sampling Adequacy. } \\
\text { Bartlett's Test of Sphericity }\end{array}$ & $\begin{array}{l}\text { Approx. Chi-Square } \\
\text { Df } \\
\text { Sig. }\end{array}$ & $\begin{array}{l}.747 \\
1087.247 \\
190 \\
.000\end{array}$ \\
\hline
\end{tabular}

\section{Academic sources as stressor}

This study analyzes the descriptive statistics of the responses of the nursing students. The study undergoes four main categories of stressors which are academic, clinical, personal and environmental. The sample responses of sources of stress among nursing students are described under four main categories in form of tables. Table 6 shows the responses of the nursing students regarding academic sources of stress. The results prove that $61.5 \%, 48.4 \%$, $47.5 \%, 47.5 \%, 39 \%$ and $49.2 \%$ of the respondents were strongly agree on the questions from 1 to 6 respectively, regarding the academic sources as stressors for the nursing student of private universities. This explains that nursing students are prone to stress through the academic sources of stress.

Table 6. Frequency Distribution (Academic sources of stress)

\begin{tabular}{|l|l|l|l|l|l|l|l|}
\hline S. No & Academic Sources of Stress & SD & DA & N & A & SA & Total \\
\hline $\mathbf{1}$ & $\begin{array}{l}\text { Frequent graded activities are } \\
\text { very stressful. }\end{array}$ & $3.3 \%$ & $3.3 \%$ & $3.3 \%$ & $28.7 \%$ & $61.5 \%$ & $100 \%$ \\
\hline $\mathbf{2}$ & $\begin{array}{l}\text { Stress level increases due to } \\
\text { getting lower grades then } \\
\text { anticipation. }\end{array}$ & $8 \%$ & $2.5 \%$ & $1.6 \%$ & $46.7 \%$ & $48.4 \%$ & $100 \%$ \\
\hline $\mathbf{3}$ & $\begin{array}{l}\text { Challenging courses and } \\
\text { missing too many classes } \\
\text { contribute to stress. }\end{array}$ & $0 \%$ & $6.6 \%$ & $12.3 \%$ & $33.6 \%$ & $47.5 \%$ & $100 \%$ \\
\hline $\mathbf{4}$ & $\begin{array}{l}\text { Inability to balance study and } \\
\text { leisure time is source of stress. }\end{array}$ & $0 \%$ & $6.6 \%$ & $12.3 \%$ & $33.6 \%$ & $47.5 \%$ & $100 \%$ \\
\hline $\mathbf{5}$ & $\begin{array}{l}\text { Inconsiderate and insensitive } \\
\text { instructors also cause stress. }\end{array}$ & $1.6 \%$ & $2.5 \%$ & $13.1 \%$ & $43.4 \%$ & $39.0 \%$ & $100 \%$ \\
\hline $\mathbf{6}$ & $\begin{array}{l}\text { Lack of expected career } \\
\text { advancement, promotion and } \\
\text { fear of future create stress. }\end{array}$ & $.8 \%$ & $5.7 \%$ & $7.4 \%$ & $36 . .9 \%$ & $49.2 \%$ & $100 \%$ \\
\hline
\end{tabular}

(SD = Strongly Disagree, DA = Disagree, $\mathbf{N}$ = Neutral, A = Agree, SA = Strongly Agree)

\section{Clinical sources as stressor}

Table 7 depicts the frequency distribution of clinical sources of stress. The results show that $44.3 \%, 31.1 \%, 23.8 \%, 34.4 \%, 29.5 \%$ were strongly agree on the questions from 1 to 6 respectively, regarding the clinical sources as stressors. This explains that nursing students are prone to stress through the clinical sources of stress.

Table 7. Frequency distribution (clinical sources of stress)

\begin{tabular}{|l|l|l|l|l|l|l|l|}
\hline S. No & Clinical Sources of Stress & SD & DA & N & A & SA & Total \\
\hline $\mathbf{1}$ & $\begin{array}{l}\text { Maintaining a balance } \\
\text { between clinical work and } \\
\text { studying increases stress. }\end{array}$ & $0 \%$ & $8.2 \%$ & $7.4 \%$ & $40.2 \%$ & $44.3 \%$ & $100 \%$ \\
\hline $\mathbf{2}$ & New clinical situations, & $.8 \%$ & $16.4 \%$ & $13.9 \%$ & $37.4 \%$ & $31.1 \%$ & $100 \%$ \\
\hline
\end{tabular}


South American Journal of Nursing

Volume 2, Issue 1, 2016

\begin{tabular}{|l|l|l|l|l|l|l|l|}
\hline & $\begin{array}{l}\text { unfamiliar patient's diagnosis } \\
\text { and treatment promote stress } \\
\text { level. }\end{array}$ & & & & & & \\
\hline $\mathbf{3}$ & $\begin{array}{l}\text { Differences between the ideal } \\
\text { practices learned in school and } \\
\text { real situations in the } \\
\text { healthcare environment cause } \\
\text { of stress. }\end{array}$ & $0 \%$ & $7 \%$ & $18.0 \%$ & $25.5 \%$ & $23.8 \%$ & $100 \%$ \\
\hline $\mathbf{4}$ & $\begin{array}{l}\text { Humiliating behavior of } \\
\text { physicians and being criticized } \\
\text { in front of patients is reason of } \\
\text { stress. }\end{array}$ & $.8 \%$ & $12.3 \%$ & $12.3 \%$ & $40.2 \%$ & $34.4 \%$ & $100 \%$ \\
\hline $\mathbf{5}$ & $\begin{array}{l}\text { Unfriendliness from more } \\
\text { senior staff and fear of making } \\
\text { mistakes in patient care is a } \\
\text { cause of stress in clinical } \\
\text { setting. }\end{array}$ & $1.6 \%$ & $12.3 \%$ & $10.7 \%$ & $45.9 \%$ & $29.5 \%$ & $100 \%$ \\
\hline
\end{tabular}

(SD = Strongly Disagree, DA = Disagree, $\mathbf{N}$ = Neutral, A = Agree, SA = Strongly Agree)

\section{Personal sources as stressors}

Table 8 explains the frequency distribution of personal sources of stress. The results show that $39.3 \%, 45.9 \%, 42.6 \%, 44.9 \%$ of the students were agree on the questions from 1 to 6 respectively, regarding the personal sources as stressors for nursing students of stress. This explains that nursing students face stress through the personal sources of stress.

Table 8. Frequency distribution (Personal sources of stress)

\begin{tabular}{|l|l|l|l|l|l|l|l|}
\hline S. No & $\begin{array}{l}\text { Personal Sources as } \\
\text { Stressors }\end{array}$ & SD & DA & N & A & SA & Total \\
\hline $\mathbf{1}$ & $\begin{array}{l}\text { Changes in sleeping } \\
\text { pattern/lack of sleep enhance } \\
\text { stress. }\end{array}$ & $0 \%$ & $15.6 \%$ & $8.2 \%$ & $39.3 \%$ & $36.9 \%$ & $100 \%$ \\
\hline $\mathbf{2}$ & $\begin{array}{l}\text { Financial problems are main } \\
\text { source of stress. }\end{array}$ & $1.6 \%$ & $11.5 \%$ & $8.2 \%$ & $45 . .9 \%$ & $32.8 \%$ & $100 \%$ \\
\hline $\mathbf{3}$ & $\begin{array}{l}\text { Decline in personal health } \\
\text { contribute a lot to stress. }\end{array}$ & $1.6 \%$ & $13.1 \%$ & $10.7 \%$ & $42.6 \%$ & $32.0 \%$ & $100 \%$ \\
\hline $\mathbf{4}$ & $\begin{array}{l}\text { Lack of confidence and } \\
\text { inability to decision making } \\
\text { enhance stress. }\end{array}$ & $0 \%$ & $13.9 \%$ & $10.7 \%$ & $44.9 \%$ & $31.1 \%$ & $100 \%$ \\
\hline
\end{tabular}

(SD = Strongly Disagree, DA = Disagree, $\mathbf{N}=$ Neutral, A = Agree, SA = Strongly Agree)

\section{Environmental sources as stressor}

Environmental factors also create stress among the nursing students. Table 9 shows that most of the students responded between neutral to strongly agree regarding the environmental factors as stressor for the nursing students. Thus, it proves that environmental factors also create stress for the nursing students.

Table 9. Frequency Stressors (Environmental sources of stress)

\begin{tabular}{|l|l|l|l|l|l|l|l|}
\hline $\begin{array}{l}\text { S. } \\
\text { No }\end{array}$ & $\begin{array}{l}\text { Environmental Sources as } \\
\text { Stressors }\end{array}$ & SD & DA & N & A & SA & Total \\
\hline $\mathbf{1}$ & $\begin{array}{l}\text { Lack of recreational } \\
\text { facilities/activities during } \\
\text { semester is a source of stress. }\end{array}$ & $1.6 \%$ & $17.2 \%$ & $14.8 \%$ & $33.6 \%$ & $32.8 \%$ & $100 \%$ \\
\hline
\end{tabular}




\begin{tabular}{|l|l|l|l|l|l|l|l|}
\hline $\mathbf{2}$ & $\begin{array}{l}\text { Difficulties with transportation } \\
\text { also a source of stress. }\end{array}$ & $0 \%$ & $11.5 \%$ & $16.4 \%$ & $35.2 \%$ & $36.9 \%$ & $100 \%$ \\
\hline $\mathbf{3}$ & $\begin{array}{l}\text { Not enough leisure time } \\
\text { creates frustration. }\end{array}$ & $0 \%$ & $8.2 \%$ & $18.0 \%$ & $39 . \% 3$ & $34.4 \%$ & $100 \%$ \\
\hline $\mathbf{4}$ & $\begin{array}{l}\text { Absence of calm and quite } \\
\text { environment in class increases } \\
\text { stress level. }\end{array}$ & $0 \%$ & $13.9 \%$ & $12.3 \%$ & $45.1 \%$ & $28.7 \%$ & $100 \%$ \\
\hline $\mathbf{5}$ & $\begin{array}{l}\text { Congested class room creates } \\
\text { anxiety. }\end{array}$ & $4.9 \%$ & $15.6 \%$ & $13.1 \%$ & $35.1 \%$ & $31.1 \%$ & $100 \%$ \\
\hline
\end{tabular}

(SD = Strongly Disagree, DA = Disagree, $\mathbf{N}=$ Neutral, A = Agree, SA = Strongly Agree)

\section{Discussion}

In the current study four main categories of stressors were selected which are academic, clinical, personal and environmental. Table 6 show the response of the nursing students was highest to the strongly agree regarding the academic stressor questions. Thus, results show that students face highest level of stress from the academic sources. Similarly, nursing students face the stress through the clinical rotation. The situations in clinical practice that produces the stress due to the differences between the ideal practice learned in the classes and real situations in the healthcare environment, indifference from more senior staff, being criticized in front of staff and patients (Pulido, et al.,2012). Thus, results (Table 7) of the current study also show that nursing students face stress through the clinical practices.

In addition, table 8show that students were majorly agrees that personal factors also create stress among the nursing students. The students feel lack of self-confidence in general. Confidence is crucial for being able and sufficient in one's profession (Kim, et al., 2010). Likewise, financial status of the students is one of the most associated factors related to stress, might be financial crisis affected the entire world and the rise in cost of living. The study finds that lack of financial support is one of the factors that contributed to stress among university students (Redhwan, 2009).

Furthermore, environmental factors also cause stress among nursing students. Table 9 clearly shows that the nursing students were agreed regarding environmental factors as the stressor for the nursing students.

Table 10. Descriptive Statistics

\begin{tabular}{|l|l|l|l|l|l|l|}
\hline & N & Minimum & Maximum & Sum & Mean & $\begin{array}{l}\text { Std. } \\
\text { Deviation }\end{array}$ \\
\hline Academic Sources & 122 & 2.17 & 5.00 & 522.67 & 4.2842 & .55863 \\
\hline Clinical Sources & 122 & 2.20 & 5.00 & 483.40 & 3.9623 & .65117 \\
\hline Personal Sources & 122 & 1.50 & 5.00 & 481.00 & 3.9426 & .79108 \\
\hline Environmental Sources & 122 & 2.40 & 5.00 & 472.6 & 3.873 & .69909 \\
\hline Valid N (Listwise) & 122 & & & & & \\
\hline
\end{tabular}

Table 10 shows the descriptive statistics of the four stressors which are considered in the current study. The current study considered academic sources, clinical sources, personal sources and environmental sources as the major four contributors to the nursing student's stress. In the table 10, nursing student's response to all the stressors is given. The mean value of the four major stressors shows the major responses of the nursing student to the options of the Likert scale. Moreover, the comparison of the stressors can be seen by the nursing student's response. Thus, nursing student's responded highest factor of stress to the academic sources of stress as the mean value of 4.2842 show that majority of the students were agree and strongly agree on the point that academic sources create stress. Similarly, the nursing students consider clinical sources, personal sources and environmental sources as stressors respectively. However, environmental sources are considered as the lowest source of stress than the other 3 categories. 
South American Journal of Nursing

Volume 2, Issue 1, 2016

\section{Conclusion}

"The current study investigates the major sources of stress among the nursing students of private universities. The sources which are considered as the stressors are academic, clinical, personal and environmental. The study reveals the moderate to high level of stress among the nursing students. The findings of the study indicate that students experience highest level of stress through the academic, however clinical and personal sources as moderate level. Furthermore, environmental stressors as the lowest stressors than the other 3 categories.”

\section{Recommendations}

The current study suggests that high level of academic stress found among the nursing students of private universities, so, it is recommended that authorities should consider this situation in the curriculum. Management should encourage the university faculty and the staff to work in cooperation with the students to improve the use of support services for the students. Further studies should consider the mediations which may provide social and psychosocial support to the nursing students."

\section{Limitations of the study}

This study has also some limitations which can be fulfilled in the further studies. This study conducts research on limited scale due to shortage of time. This is a descriptive study that is done among nursing students of only private universities. The findings of this study are based on the quantitative techniques, so the qualitative approach can also be used to have the better analysis and comparison.

\section{References}

[1.] Cohen-Scali, V. (2003). The influence of family, social, and work socialization on the construction of the professional identity of young adults. Journal of career development, 29(4), 237-249.

[2.] Edwards, D., Burnard, P., Bennett, K., \& Hebden, U. (2010). A longitudinal study of stress and self-esteem in student nurses. Nurse education today, 30(1), 78-84.

[3.] Edward, K. L., Warelow, P., Hemingway, S., Hercelinskyj, G., Welch, A., McAndrew, S., \& Stephenson, J. (2015). Motivations of nursing students regarding their educational preparation for mental health nursing in Australia and the United Kingdom: a survey evaluation. BMC nursing, 14(1), 1.

[4.] Eswi, A. S., Radi, S., \& Youssri, H. (2013). Stress/stressors as perceived by baccalaureate Saudi nursing students. Middle-East Journal of Scientific Research, 14(2), 193-202.

[5.] Findik, U. Y., Ozbas, A., Cavdar, I., Topcu, S. Y., \& Onler, E. (2015). Assessment of nursing students' stress levels and coping strategies in operating room practice. Nurse education in practice, 15(3), 192-195.

[6.] Hayes, B., Douglas, C., \& Bonner, A. (2015). (Article 4) Work Environment, Job Satisfaction, Job Stress and Burnout among Haemodialysis Nurses. Job Satisfaction, Stress and Burnout in Haemodialysis Nurses, 155.

[7.] Kim, M., \& Hwangbo, H. H. (2010). Randomized trial evaluating the aroma inhalation on physiological and subjective anxiety indicators of the nursing students experiencing the first intravenous injection. International Journal of Bio-Science and Bio-Technology, 2(4), 1-9.

[8.] Lim, S., Cortina, L. M., \& Magley, V. J. (2008). Personal and workgroup incivility: impact on work and health outcomes. Journal of Applied Psychology, 93(1), 95.

[9.] Pryjmachuk, S., \& Richards, D. A. (2007). Predicting stress in pre-registration nursing students. British Journal of health psychology, 12(1), 125-144.

[10.] Pulido-Martos, M., Augusto-Landa, J. M., \& Lopez-Zafra, E. (2012). Sources of stress in nursing students: a systematic review of quantitative studies. International Nursing Review, 59(1), 15-25. 
[11.] Redhwan, A. A. N., Sami, A. R., Karim, A., Chan, R., \& Zaleha, M. (2009). Stress and coping strategies among management and science university students: A qualitative study. The International Medical Journal of Malaysia, 8(2).

[12.] Shaban, I. A., Khater, W. A., \& Akhu-Zaheya, L. M. (2012). Undergraduate nursing students' stress sources and coping behaviours during their initial period of clinical training: A Jordanian perspective. Nurse Education in Practice, 12(4), 204-209.

[13.] Zhao, F. F., Lei, X. L., He, W., Gu, Y. H., \& Li, D. W. (2015). The study of perceived stress, coping strategy and self-efficacy of Chinese undergraduate nursing students in clinical practice. International journal of nursing practice, 21(4), 401-409. 


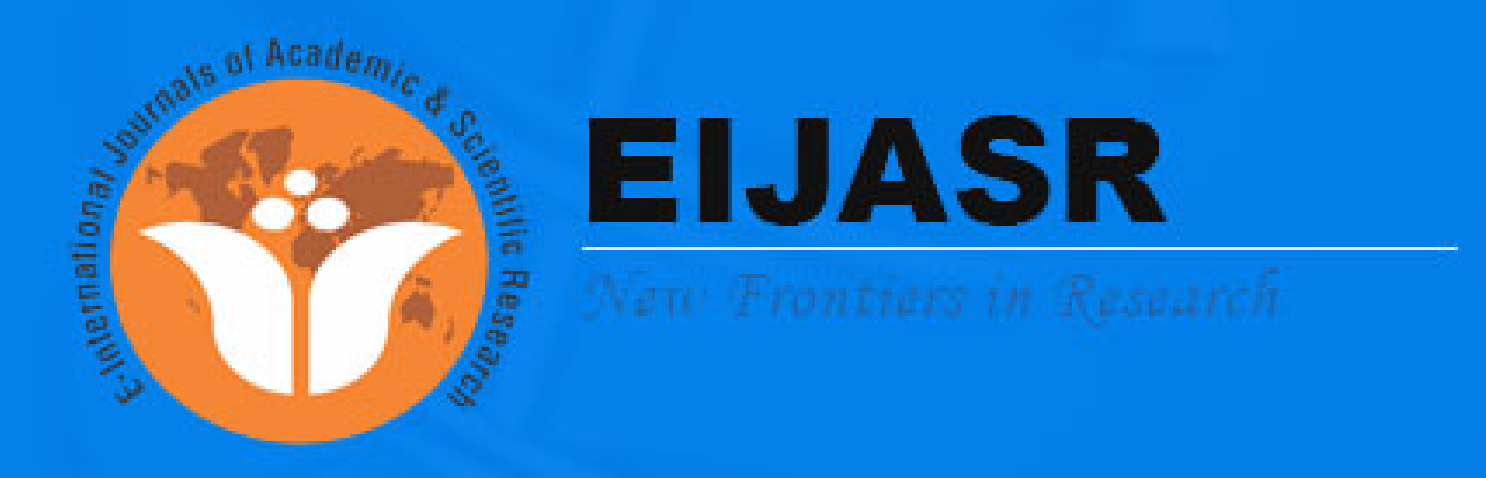

Lot A, Goedverwagting, Sparendaam, East Coast Demerara, Guyana, South America.

Telephone: (+592) 2225224 / (+592) 2225225 E-mail: ejournal.assist@tau.edu.org 